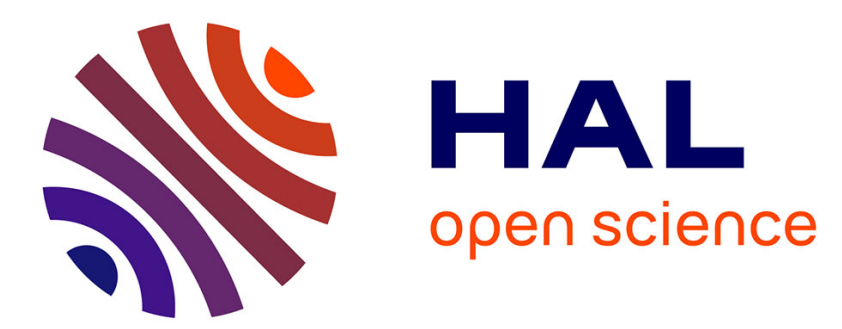

\title{
Does fertility respond to work and family reconciliation policies in France?
}

Olivier Thevenon

\section{To cite this version:}

Olivier Thevenon. Does fertility respond to work and family reconciliation policies in France?. 2009. hal-00424832

\section{HAL Id: hal-00424832 \\ https://hal.science/hal-00424832}

Preprint submitted on 19 Oct 2009

HAL is a multi-disciplinary open access archive for the deposit and dissemination of scientific research documents, whether they are published or not. The documents may come from teaching and research institutions in France or abroad, or from public or private research centers.
L'archive ouverte pluridisciplinaire HAL, est destinée au dépôt et à la diffusion de documents scientifiques de niveau recherche, publiés ou non, émanant des établissements d'enseignement et de recherche français ou étrangers, des laboratoires publics ou privés. 


\title{
Does Fertility Respond to Work and Family-life Reconciliation Policies in France?
}

\author{
Olivier Thévenon*
}

In Noriyuki Takayama and Martin Werding (eds., 2009), Fertility and Public Policy: How To Reverse the Trend of Declining Birth Rates, Cambridge MA and London UK: MIT-Press, chapter 10.

\section{Introduction}

For the past two years, France has enjoyed fertility rates approaching replacement level, with a total fertility rate of 1.98 in 2006 and 2.00 in 2008. After a ten-year period of slow growth, the fertility rate has thus reached its highest level in about thirty years (Prioux, 2007), placing France in top position among European and other OECD countries. However, this high level of fertility is somewhat puzzling, because most of the trends impacting the transition to adulthood that have emerged in Western countries since the 1970s may also be seen in France. Young people have increased their educational investment, delayed their entry onto the labour market, their departure from their parents' homes or their entry into parenthood. The changes have been especially significant for women, whose labour force participation continues to increase. The young generations face relatively high unemployment rates and have become increasingly uncertain about their labour force status.

Demographic changes are also shaped by the transformation of values, such as those related to the increasing concern about gender equality, or the affirmation of what Giddens and subsequent authors have named the "individualism of society". Such changes may help to explain the increase in non-marital cohabitation, the use of contraceptives and birth control, or the rise in divorce. However, one should be cautious about these changes in values since there is also some resistance to gender equality, as reflected by the very limited changes in the division of domestic and care activities between men and women.

All these factors help explain why the younger generations are inclined to delay childbearing in France, like in other Western countries, leading potentially to a permanent low fertility situation (Kohler, Billari, Ortega, 2006; Morgan and Taylor, 2006; Lutz et al., 2006). However, although France exhibits most of the above-mentioned trends, fertility remains at a relatively high level compared with other continental or southern European countries. This situation reflects some specific characteristics of fertility behaviour: a relatively low proportion of women remaining childless; an increasing trend towards a two-child norm and a standardization of childbirth timing. There are also fairly small differences in family size across social classes. All these factors produces relatively stable fertility rates after controlling

\footnotetext{
* I would like to thank Didier Breton, France Prioux, Laurent Toulemon, Pierre Courtioux, Nadine Laïb, Sylvie Le Minez and Benoît Mirouse for their kind help in providing data and figures. Original sources can be found in the references at the end of the paper. Special thanks also to Catriona Dutreuilh for the edition of English and to Laurent Toulemon for continuous discussion on the issues related to the present chapter, to the anonymous referees and the editors. The usual disclaimer applies.
} 
for tempo changes (Toulemon et al., 2008). All these characteristics are detailed in the first part of this chapter.

One factor that explains this situation is the longstanding family policy implemented in France, especially since World War II. With its diversity of values and principles, France has a variable and often contradictory position in the classification of Western welfare systems (Meulders and O'Dorchai, 2007; Thévenon, 2006). The second part of this paper briefly presents the background to the family policies, their relation to families' living standards and how they have been progressively influenced by the issue of the work-family balance. Support to families, and especially to working parents, is relatively comprehensive, i.e. quite diversified and continuous over the entire child-rearing period. A key difference with respect to certain other Continental European countries is that women find relatively broad support for combining entry into employment and motherhood, i.e. full-time employment and the birth of the first child (Thévenon, 2006).

However, it is difficult to assess the effective impact of these family-friendly policies on fertility behaviour. One obvious reason is that the family policy package forms a whole which does not simply add up to the sum of its parts, as stated by Héran (2002). There is no doubt that the entire set of family policy instruments contributes to a favourable environment for fertility and the well-being of families; yet at the same time, the interconnection of instruments makes it difficult to assess the impact of each one individually. In spite of this limitation, the third section of this paper reviews the studies carried out on the impact of these policies on fertility and related labour market behaviour. We first review cross-country comparisons which conclude that the effect of direct financial support on fertility is relatively weak but which highlight the impact of policies targeting the labour market. The analyses for France also point to a rather limited impact on fertility of cash and benefit transfers, but stress the influence of labour market policies on the female workforce and the work-life balance. We argue that this comprehensive and longstanding policy creates a secure climate for simultaneously entering employment and motherhood. The comprehensive support delivered to working parents, the continuous help received by parents with young children, and the variety of benefits granted to address the diverse needs of families are certainly crucial ingredients of the "trust" needed for policies to be effective. This may explain why a fairly low proportion of women remain childless and why having a child has only a weak negative impact on the probability of women working full-time. Extensive childcare support (through paid parental leave, childcare benefits, childcare services, early enrolment in preschool, and the provision of out-of-school care) is another reason why women do not forgo a second or third child and also explains why the decision to have children or to work is less dependent on socioeconomic status in France than in other countries.

\section{Fertility trends and family size}

\section{I.1. A long-term decrease in fertility...}

The recent high fertility rate is viewed as a sign of the optimism of the French population, since for the second consecutive year it has stood at its highest level since 1982 (Prioux, 2007). France was the first European country to post a total fertility rate (TFR) of 2.0 in 2006 (1.98 excluding the French overseas departments and territories), an increase of $2.9 \%$ with respect to 2005. Although fertility rates still remain slightly lower than in English speaking countries, France, together with Iceland and Ireland, has one of the highest rates in Europe. 
However, this fertility rebound also concerns other countries with different policies, such as the UK or the Nordic countries where the TFR is now higher than 1.8 children per woman. Nevertheless, France holds a singular position in continental Europe, where two groups of countries stand out (Prioux, 2007): on the one hand, Belgium, Luxembourg and the Netherlands, which show a relatively stable TFR around the intermediate level of 1.7; on the other hand, Germany, Austria and Switzerland, with fertility rates of 1.3 to 1.4 respectively and whose situation is therefore closer to that of low-fertility countries. In fact, the fertility rates have recently started to increase on average in all European countries, whereas this is not detectable for all OECD countries.

Focusing exclusively on total fertility rates can be misleading since they are very sensitive to the timing of childbirth. In particular, a postponement of births causes a decrease in the period rate which is based on the assumption of stable birth timing. Thus, the usual TFR leads to an underestimation of the period fertility level. For that reason, more sophisticated indexes that control for differences in fertility by birth parity and changes in interval between births are preferred (Rallu and Toulemon, 1994; Sobotka et al., 2005; Bongaarts and Feeney, 2006). The Parity and Duration Total Fertility Rate (PDTFR, also named Period Average Parity) is a more consistent estimate of period fertility (Toulemon and Mazuy, 2001). Figure 1 shows a value of around 2.0 children per woman in France, which is very close to the cohort completed fertility rate estimated for the corresponding cohorts.

\section{Figure 1: Long-term fertility trends in France}

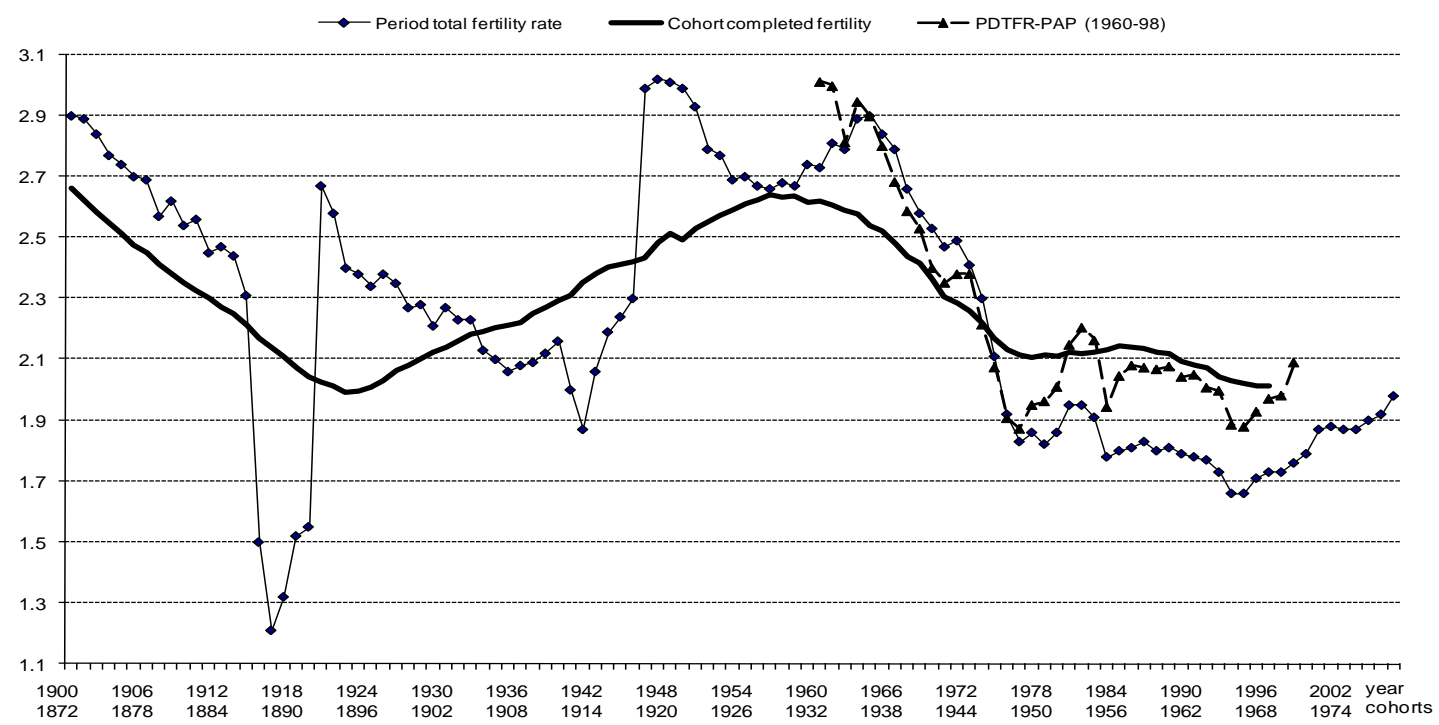

Source: Toulemon, Pailhé, Rossier (2008)

This graph also illustrates the long-term trends in fertility rates over the 20th century. At first glance it tends to alter our assessment of the long-term decline in fertility, since the current level of cohort fertility appears quite similar to that of the cohorts born around 1890 and 1900. However, strong variations can be observed for cohorts born in between: for the cohorts born up to the end of the 1960s fertility rates increased rapidly, but a decrease of similar intensity is observed after that. One major change between the two points in time is the dramatic decrease in infant mortality over the century. Some $9 \%$ of children died in their first year in 1900 whereas the rate is now below $0.5 \%$ (Toulemon et al., 2008). 


\section{I.2. ... or delayed parenthood?}

Another important change over the last decades concerns the timing of childbirth. Figure 2 illustrates the change in the average age at maternity by birth parity for women born from 1920 to 1965. The U-shape of the curves shows that women born between 1940 and 1945 had their children at an earlier point in their life-cycle, e.g. at the age of 26 years on average, compared to 28.5 years for women born in 1920. A progressive postponement of births is observed, however, for women born after the Second World War. Figure 2 also reveals that the decrease in average age at first maternity is quite limited compared with the trend for the last child. The reduction of the mother's age at the birth of the last child is explained by two factors of roughly equal importance: successive births are occurring over a shorter period, but large families are becoming progressively less frequent (Daguet 2002).

Figure 2: average age at maternity, by parity

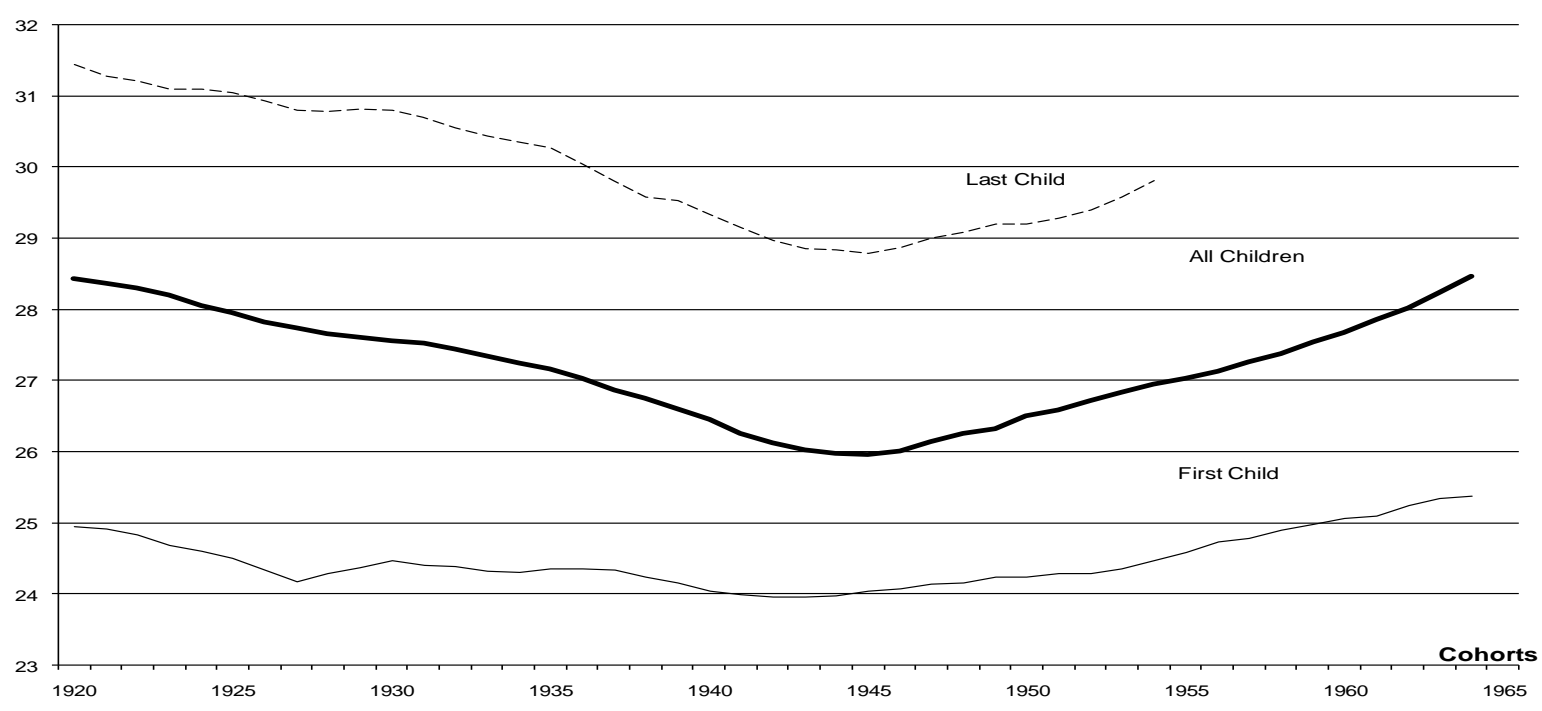

Source: Toulemon, 2003.

Trends changed for women born after 1945 who had their children at later ages. The postponement of the first birth is sufficient in itself to explain the rise in the average age of women at childbirth. For women born in 1970 (not illustrated in the figure), the average age at first birth was around 27 years, and the average age at maternity is expected to be about 30 years (Toulemon, 2003). Prioux (2007) reported that the average age at childbirth has continued to increase for women born after 1970. This is estimated at 29.9 years for women born in 1973, i.e. one year later than for the cohort born in 1966. Prioux also argues that the increase in age at childbirth has already started to slow down slightly, and may probably level off for subsequent cohorts. However, this trend should not be misinterpreted since it is the result of a balance between a decrease in fertility rates at ages below 35 and an increase in fertility rates at older ages. Thus, the dominant trend since the early 2000s has been an accelerated increase in fertility rates after age 30, as if most of the women born in the seventies who postponed childbearing have now "caught-up" their delay.

\section{I.3. A reduction of family size to two children}

Changes in family size have also been considerable over the last decades. Basically, for cohorts born in the early 1960s (i.e. the cohorts for which the completed fertility rate can be estimated), the fertility rebound recorded after the age of 30 has not been sufficient to 
make up for the delay in family formation. For cohorts born after 1964, the decrease in completed fertility has continued but at a slower pace.

In a medium-term perspective, the decrease in average fertility for post-1930 cohorts reflects a decrease in the proportion of large families (i.e. with three or more children) and a tendency to limit family size to two children (Figure 3). The proportion of women with four children or more has fallen 2.5-fold (from 25\% to 10\%), while the proportion of women with two children has increased by half from $27 \%$ to $40 \%$. By contrast, the percentage of women with either one or three children has remained relatively stable at around $20 \%$. 
Figure 3: Distribution of women by completed fertility

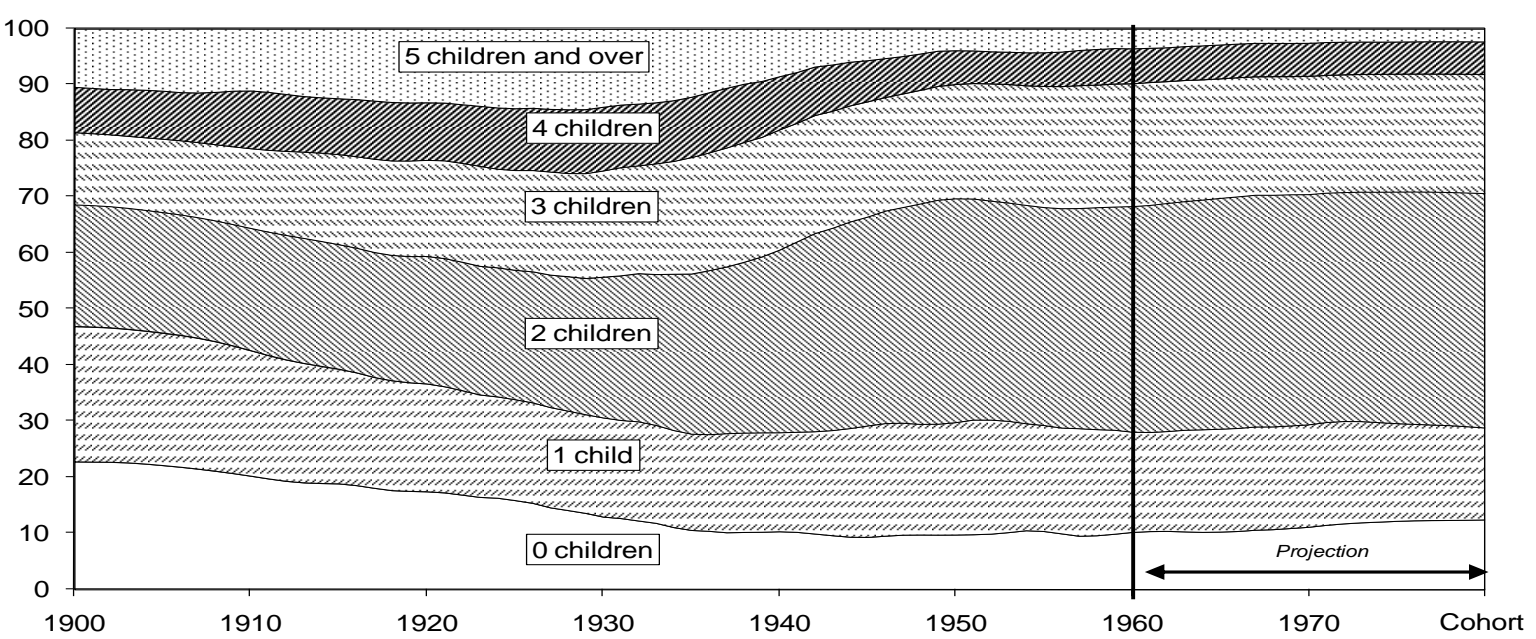

Source: Toulemon, Pailhé, Rossier (2008)

\section{l.4. A low proportion of childless women}

The parity progression ratios based on duration-specific fertility rates shown in Figure 4 provide more precise information on recent trends. Basically, they confirm a decrease in the propensity to have a third or a fourth child. The progression to the first child (a0) also appears to be declining slightly, but this may be due to the postponement of family formation. By contrast, subsequent parity progression ratios are quite stable, indicating that the probability of a progression to the second (a1), third (a2) and fourth (a3) child has not significantly changed since 1975 . Thus, the probability of remaining childless is certainly increasing, but the proportion of childless women still remains quite low in comparison with other European countries. Thus, in 2002 the actual percentage of childless women in relation to those with completed families was about 7\% in France, versus around 12\% in Germany or Austria (see Breton and Prioux). Toulemon (2003) estimates from a larger survey on families that only about $10 \%$ of French women born in 1950 remained childless; the proportion has been stable since 1935 and is expected to increase somewhat in the future.

\section{Figure 4: Period parity progression ratios}

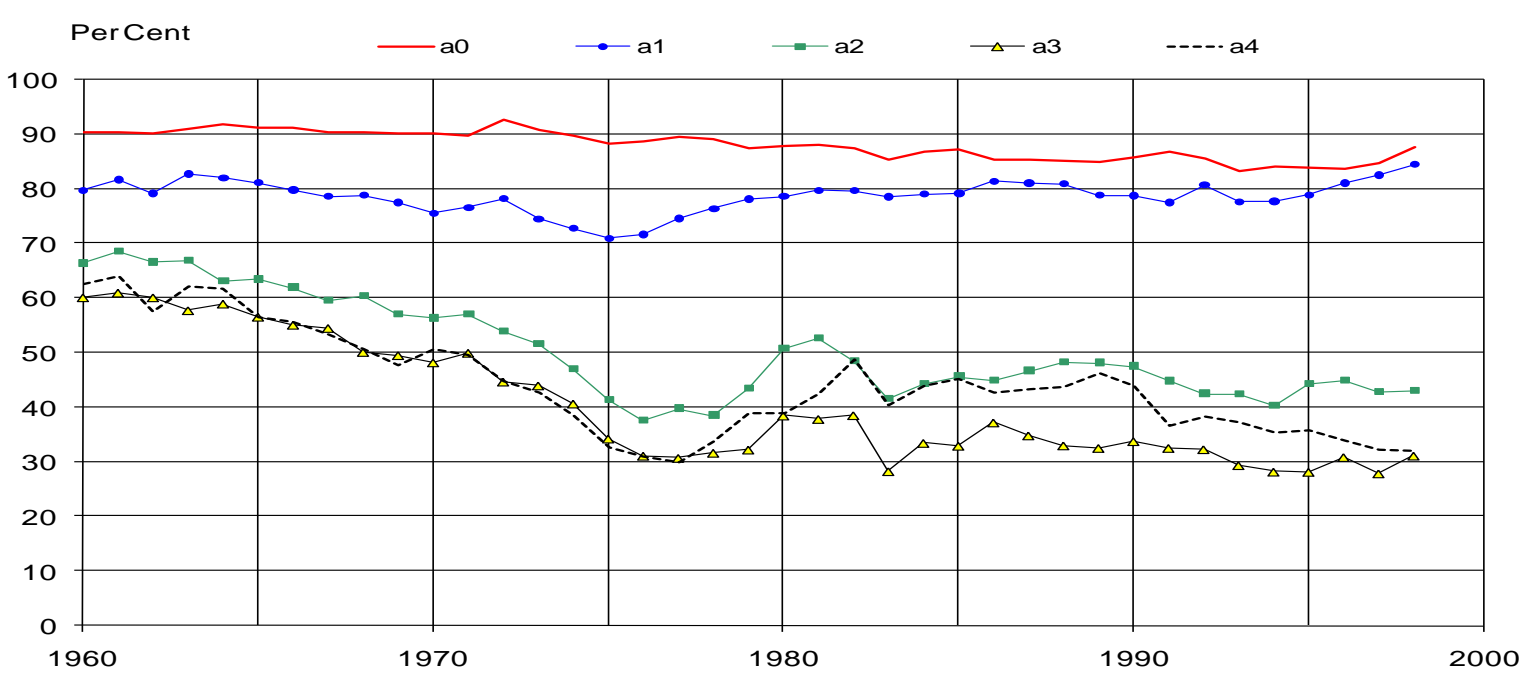

Source: Toulemon and Mazuy (2001) 


\subsection{Limited differences in fertility across education levels and social groups}

Differences in family size between social groups are relatively small and decreasing slightly. There are, however, some differences in fertility behaviour by educational background. Robert-Bobée and Mazuy (2005) analysed these differences, taking account of changes in school leaving age across cohorts. For each of these cohorts, they distinguished individuals with a short period of education, i.e. with 2 years below the mean school leaving age of their birth cohort, from those with a long period of education (i.e. with 2 years more than the mean age). They thus defined high- and low-education groups, each comprising around $30 \%$ of the cohort on each side of the central intermediate group.

For both men and women, the average number of children has declined at all educational levels, and the differences between groups are decreasing (Figure 5). For men, these differences are relatively moderate and even decreasing over cohorts. Nevertheless, men with a short period in education remain childless slightly more often, and they are also more likely to have three or more children. The contrasts are greater for women than for men. Among the cohorts born in 1950-54 and observed at the age of completed fertility, the average number of children ranged from 1.8 among women with more education to 2.4 for women with less. Women with a higher education more frequently remain childless $(15 \%$ of women with a longer education born between 1945 and 1949 compared to 9\% for those with medium education). There are basically two explanations for this: they less frequently live with a partner, but those living with a partner also have fewer children and remain childless for longer.

Figure 5: Differences in fertility by length of education

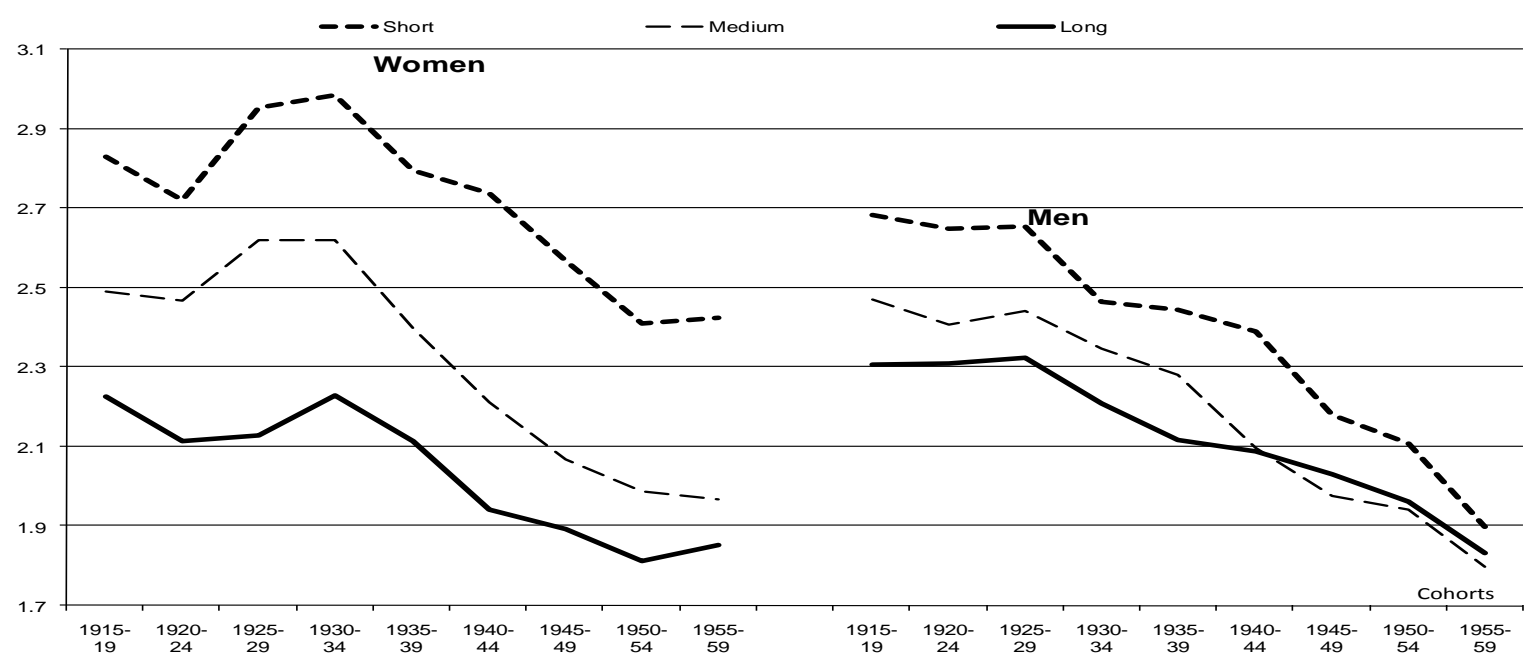

Source: Toulemon, Pailhé, Rossier (2008)

Differences in educational background also have a significant impact on the interval between births. People with a longer experience in education have a longer period without children, but the interval between the first and second child is also reduced. By contrast, individuals with low education have their first child sooner, but the second birth occurs significantly later (Robert-Bobée and Mazuy, 2005). The two-child family is also more widespread among the highly educated whereas the proportion of three-child families has continued to rise for less educated women. Only the proportion of very large families, with at 
least four children, has fallen for less educated women, but in a smaller proportion than for women with a higher educational level.

All in all, differences by socioeconomic status are relatively small compared with other European countries. For instance, France is less dichotomous than Britain, where more women, especially among the most educated groups, decide to remain childless, (Ekert-Jaffé et al., 2002). France is also characterized by a growing and relatively high proportion of births outside marriage, which illustrates the de-standardization of pathways to childbearing: in 2006, they represented 50.5\% of all births in France (Pla, 2007), versus an average of only one third of all births in EU 25.

\section{I.6. Lower-than-intended fertility?}

One basic argument used to advocate family policies is that men and women do not have the number of children they would like. This hypothesis is not easy to validate, however. The first challenge is to quantify accurately the "desire" or "intention" to have children, since the size of the gap varies considerably according to the measurements used. The second challenge concerns the interpretation of this gap, since it may refer to constraints that are internalized by individuals. Thus, a respondent's answer on fertility intentions is very sensitive to how the question is formulated. Moreover, intentions may vary considerably according to the institutional and policy context, so interpreting the gap between intended and actual fertility is a delicate issue.

Recent surveys conducted in Europe show large differences in the ideal number of children across the EU members (Testa, 2006). France is among the countries where this "ideal" is the highest (2.66 compared to the EU-15 average of 2.29 (only Ireland has a higher number with 2.80, Denmark comes a close third with 2.63), whereas some countries like Austria, are characterized by a below-replacement family size ideal. The author also estimates the "ultimately intended family size" by summing the number of children already born and those that individuals still intend to have in the future, and measures the gap between actual and intended family size. France ranks sixth among the EU-15 member states. However, some authors like Lutz (2007) argue that the gap vanishes in certain countries when tempo-adjusted period fertility rates are used. That is the case in Austria, for instance, but not in France.

One reason for this gap may be related to the growing perception that fertility can be planned, even if not perfectly controlled. The legalization of abortion and the dissemination of contraception during the past forty years have certainly boosted this perception. In the late 1960 s, $15 \%$ of pregnancies resulting in a birth were intended, and the proportion of planned births rose from 59\% in 1970 to $83 \%$ in 1995. Prospective parents now expect to choose not only the number of children, but the timing of their births. Régnier-Loilier and Léridon (2007) consider that the intervals between successive births are now rarely left to chance. For example, closely-spaced births are unusual. Whereas in the mid 1960s, almost one second birth in five occurred in the calendar year following the first birth, the proportion fell to $10 \%$ in the early 1980s and to $8 \%$ ten years later (Prioux, 1994).

Yet control over fertility is by no means perfect, since the share of "unintended" pregnancies remains very high in France. When assessing the effectiveness of birth control, the number of abortions must also be taken into account, after which about $36 \%$ of pregnancies may be estimated as "unintended". In a survey on the analysis of fertility intentions, Toulemon and Testa (2005) found that the majority of individuals (58.5\%) were hesitant about their intentions to have children. Altogether 6 respondents in 10 reported having no firm childbearing intention in the next five years. Thus, intentions are only one factor among many to explain births. Nevertheless, the authors noted that the predictive value 
of intentions varies with the level of education: higher educated individuals seem to benefit from better conditions in which to fulfil their intentions, or they anticipate their behaviour better (five years later 63\% had realized the intentions they had reported in 1998, compared with $48 \%$ for the population as a whole).

To summarize, France has relatively high fertility at near-replacement rate and the TFR has been rising since the mid 1990s. This is a rather singular trend with respect to the other countries of continental Europe. Motherhood is clearly postponed but less so than in many European countries. However, the recent rebound in total fertility rates is clearly due to the process of birth postponement. For completed fertility, the gap between the rate recorded for the baby-boomers and for younger cohorts is about half a child (2.6 children per woman born in 1940, more than 2.1 per woman born in the 1960s). However, younger cohorts seem likely to achieve a level that is scarcely lower, so cohort fertility should remain stable at around (or a little above) 2.0 children per woman, while the mother's age at birth has increased.

Childlessness among French women is significantly less frequent than in other European countries, and the proportion of families with three children or more still remains higher than in most European countries despite a more habitual restriction of family size to two children. For the cohorts born after 1945, the distribution of family size was very stable, with about $10 \%$ of women remaining childless, $20 \%$ having one child, $40 \%$ having two children, $20 \%$ having three and $10 \%$ having four children or more.

Despite this apparent stability, a gap continues to exist, at aggregate level, between actual fertility behaviour and intentions. Part of this gap may certainly be attributed to the obstacles that prevent individuals from realizing their intentions. Clearly, government policies are among the factors that can help to tackle these obstacles. They may even contribute to the shaping of fertility intentions.

\section{A Family-friendly State}

\section{II.1. High investment, but diverse objectives}

It is a well-documented fact that family policy has a long history in France and that fertility has traditionally been a political concern ${ }^{1}$. Compared to other OECD countries, public investment in families with children is relatively high. France even exhibits the highest scores in 2005, with about $3.8 \%$ of GDP spent in family benefits, cash payments, spending on services and tax breaks for families, compared to the average of 2.4\% (Durand et al., 2009). This situation is the result of a longstanding historical process, which has led to a compromise between various political ideologies and objectives. This compromise remains rooted in a dual historical tradition: on the one hand family policy that began with the protection of children and assistance to children of deprived families, and on the other, the new post-World War II framework for social protection which made a point of safeguarding the incomes of families with children (and large families especially) (Damon, 2006). The issue of fertility is also a traditional underlying concern, but in the past decade it has been partly reshaped by the issue of reconciling the work-life balance. As a consequence of these developments, current family policy is a compromise between different objectives and has inevitably become somewhat ambiguous (Thévenon, 2006).

\footnotetext{
${ }^{1}$ This may also explain the growing complexity of the French system of assistance to families. As quoted by Fagnani (2006), "successive government attempts to simplify the family benefit system have resulted in only piecemeal measures which have reinforced rather than reduced complexity. As a result, French family policy is often qualified as 'a swarm of bats"'.
} 
Current family policies in France are characterized by four salient features. First, support is still primarily designed to alleviate the impact of children on the standard of living of households, and thus benefits all families including the richer ones. Growing concerns about employment, gender equality, child poverty and so forth have, however, progressively reshaped the scope and content of family policy for reconciling work and family life. In this perspective, children now have access to childcare services and preschool from a very young age and this early access is expected to benefit the development of children, their school achievement and to help parents balance work and family life. As a consequence, expenditures in childcare and early education services score at a relatively high level: $1.6 \%$ of GDP compared to the OECD average of $0.87 \%$. Nevertheless, the development of support over the last decades has been driven by the aim of fostering a strategy of dual choice: the "choice" for parents (actually women) with children under preschool age to stay at home or go out to work; the "choice" of the mode of childcare for working parents with pre-school children. Working parents with young children consequently benefit from a continuum of support in cash and services. By contrast, the support received by working parents from their employer appears to be comparatively limited (Adema and Thévenon, 2008).

All in all, the package of support received by families from the state is very comprehensive in comparison to other countries. However, although the amount spent for all families is quantitatively quite considerable, the level and type of support actually received vary considerably with the socioeconomic status of the family.

\section{II.2. Income protection and fertility: two early family policy objectives}

As already stated, income transfers via the tax and benefit system constitute the first pillar of support received by families. Cash family benefits are important since they represent about half the benefits paid to families (Chart 7). They were introduced with the new social protection system in 1945 in a form that has hardly changed up to the present. Only families with at least two children receive the fixed, non means-tested benefits. The amount per child increases with the number of children, and a variety of pre- and post-birth payments are also included. Transfers to families are also made through income tax reduction via the "quotient familial" mechanism (a coefficient which operates by reducing the household's income tax according to the number of children) introduced into the income tax system in 1945. The transfers constitute an important share of the support provided to families since they represent about $0.7 \%$ of GDP - equivalent to one third of the total spending on families. This mechanism was designed to reduce the cost of raising children and provides tax reductions that are particularly large for families with at least three children or more. Since tax reductions are proportional to the basic taxable income, the quotient familial is especially beneficial to large richer families (see Box 1). It was explicitly designed as an incentive to boost fertility, and in particular to increase the propensity to have a third child (Thélot and Villac, 1998). The pro-natalist argument continues to shape state family policy, although recent surveys have shown that this is no longer very well perceived in public opinion, and that greater emphasis is now placed on the notion of children's rights (Letablier et al., 2002). Moreover, the above-mentioned changes in fertility and conjugal behaviour (illustrated by the transition to the two-child norm and the increase in the number of single parents) have given rise to debate on the appropriateness of the family benefit concept and the quotient familial. Despite some attempts at reform, up to now no consensus has emerged that will fundamentally change the policy baseline. 
In the period just after World War II, support was mainly focused on large families and based on a traditional male-breadwinner household. The 1970s were characterized by the increase in assistance to families with temporary economic or social difficulties and new benefits were created to help people facing social or family problems. These were reserved for a specific population and were means-tested. Lone parents with children under the age of 3 could claim for a single-parent benefit called Allocation pour Parent Isolé (API). Housing benefits were also created during the 1970s, with amounts depending on the composition of the family. In 1972, a childcare benefit for working mothers was also established. The end of the 1970s marked a turning point, and the focus of family policies gradually shifted away from fertility to the issue of reconciling work and family life.

\section{Box 1: Family-based tax allowances in France}

This mechanism, original to France, is a "family ratio" ("quotient familial") used to calculate income tax. Its basic purpose is to compensate for the cost of children by taking the presence of a partner and children into account in the calculation of income tax ${ }^{2}$. The quotient familial operates as follows: total household income is divided by the number of "adult equivalents" in the household, and the relevant tax rate is applied to this income per adult equivalent. The resulting tax rate is then applied to household income according to the following rules:

- If $\mathrm{R}$ is the household's taxable income;

- calculate a number $\mathrm{N}$ of units depending on the family size: one unit for each adult (either married or in registered partnership), 0.5 units for each child up to parity 2, one unit for each child after the third child or for the first child of a single-parent family (usually);

- the "family ratio" $\mathrm{Q}$ is equal to $\mathrm{R}$ divided by $\mathrm{N}$;

- the marginal income tax $\mathrm{t}$ is an increasing function of $\mathrm{Q}$, and not of $\mathrm{R}$;

- the tax T owed by the household is equal to : $t(Q) * R-v(Q) * N$, where $v(Q)$ is determined to ensure that there is no discontinuity in the function $\mathrm{T}(\mathrm{R})$ when $\mathrm{N}$ remains constant. Note also that $\mathrm{t}$ is progressive.

Thus, for households with the same income level, a family with three children will pay less than a family with only one child. The tax incentive to families is more than just a lump sum tax reduction per child - as would be the case if $\mathrm{t}$ and $\mathrm{v}$ depended on $\mathrm{R}$ and not on $\mathrm{Q}-$ but increases with the income $\mathrm{R}$. An extra child gives rise to a lump-sum tax reduction $\left(0.5^{*} \mathrm{v}(\mathrm{Q})\right.$ or $\mathrm{v}(\mathrm{Q})$ according to the birth order of the new child, plus a reduction of $\mathrm{t}(\mathrm{Q})$ since Q decreases. However, the "quotient familial" is not a tax credit as such: low income households who are exempt from income tax do not benefit from it at all, and households paying low income tax receive only a small tax reduction. Hence, because of its counter-redistributive effects, there is a ceiling for the tax reduction generated by the "family ratio": $€ 2,200$ a year for a first or second child in $2007, € 4,400$ a year for a child of parity 3 and above or for the first child of a one-parent family.

Using micro-simulation models, the total "cost" - or rather loss to the government budget - of the "quotient familial" was estimated at $0.7 \%$ of GDP in 2004, or one third of the total amount of cash benefits for families. This confirms the crucial role played by the "quotient familial" in reducing the financial burden of families.

Further tax reduction is granted to compensate for 'external' childcare costs, when the household makes use of a childminder or a day nursery. A total of $25 \%$ of childcare costs paid by parents can be deducted from their tax bill, up to a limit of $€ 575$ per child under age 7 .

Households recruiting a home care assistant can also deduct $50 \%$ of their expenses, up to a limit of $€ 10,000$ (€20,000 for people with disabilities), thereby reducing their tax bill by up to $€ 5,000$.

\footnotetext{
${ }^{2}$ The rationale for this mechanism lies in the 13th article of the Declaration of Human and Citizen's Rights of 1789, which is incorporated in the current French Constitution. This article states that tax owed by households must depend not just on income, but on their "contributory capacity". This notion has traditionally been interpreted as imposing a tax schedule that takes family size into account, and the French Constitutional Court has regularly reminded Parliament that it cannot create a new tax or change an existing one without taking into account household income in relation to family size, and limiting the impact accordingly.
} 


\section{II.3. A growing but ambiguous focus on the work-life balance}

Support to working mothers was developed in an ambivalent context caught between two movements: one that promoted family values and focused on large, traditional families, and the other, feminist, movement that advocated the individualization of social rights and the participation of women in the labour market (Commaille et al., 2002; Revillard, 2006; Fagnani, 2008). The issue of reconciling work and family life developed during the 1970s and 1980s. It added the development of childcare services as an objective, alongside the education and development of children. Nevertheless, support to working women developed without clear focus, notably because family policies remained in force throughout and were conducted independently of policies for women's rights and gender equality (Strobel, 2004).

This ambiguity grew during the 1980s and 1990s because family policy evolved in a context of severe budgetary restrictions, and was more directly subordinated to employment concerns. Some authors even argue that family policy was progressively shaped as an instrument of employment policies on two fronts: unemployment and the development of domestic and personal services (Martin et al., 1997; Fagnani, 2007). The Allocation Parentale d'Education was created to encourage working mothers to leave the labour market temporarily for childrearing (and thus reduce the job queue). Depending on their prior activity, mothers with 3 children could obtain a fixed allowance if they stopped working or switched to part-time work until their youngest child's third birthday. This benefit was extended to mothers with 2 children from 1994. The 2004 reform of the Prestation d'Accueil du Jeune Enfant (PAJE) enables parents to interrupt their employment from the birth of the first child for a period of up to six months, with the possibility of extending this to three years for a second or a third child, in which case the parents receive the Complément de Libre Choix d'Activité (CLCA), a monthly parental care allowance of €522. Although the PAJE is only provided for six months, the extension of parental leave support for the first child represents a significant paradigm change, since policies prior to that reform aimed rather at postponing the decision to resume work or stay at home only after a second or a third birth ${ }^{3}$ (Thévenon, 2006). By contrast, women with one child were encouraged to remain in (full-time) employment, thanks to a high level of support through childcare and preschool services. In 2005, the amount spent on parental leave benefit (APE and CLCA) represented 9\% of family support, approximately the same as the total amount spent on childcare and preschool structures by the state and the municipalities (Figure 6).

\footnotetext{
${ }^{3}$ Note also that parents with a third child can also opt for the Complément Optionel de Libre Choix d'Activité (COLCA), introduced in 2006, that allows parents to leave their employment for a shorter period (1 year compared to the 3 years of the CLCA) with a higher payment. The parent must choose his/her option before the birth of the child.
} 


\section{Figure 6: Distribution of spending on families in $\mathbf{2 0 0 5}$}

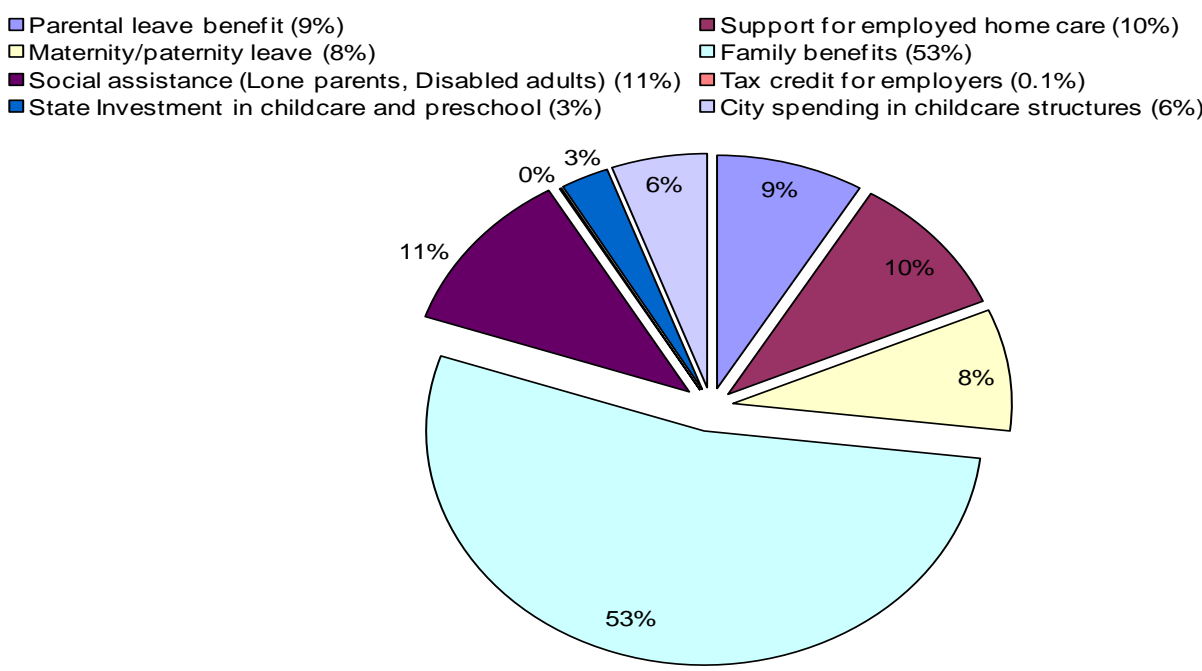

Income tax relief is not included in this distribution.

Source: authors' calculations from data reported in CAS (2007), Rapport sur un service public pour la petite enfance, http://www.strategie.gouv.fr/IMG/pdf/Rapport_SPPE_VF14022007-2.pdf.

In parallel, individualized and flexible home care services were developed, supported by tax reductions for households employing family carers at home, thereby reducing the cost of childcare and creating employment. Subsidized childminders, allowances and tax reductions for households paying childcare costs, were also introduced in the early 1980s. Since 1980, an allowance has been paid to families with children aged under 3 (later extended to children under 6) who are cared for by a registered childminder. In 1986, a tax allowance was introduced for families who employ nannies in their own home, i.e. richer families than those relying on the local day nursery or a registered childminder. Such parents are eligible to deduct half the cost of childcare from their taxable income. This mechanism provides sizeable support to families since it represents about $10 \%$ of their spending on childcare. In 2005, about $45 \%$ of children from birth to 3 years were beneficiaries of individual childcare benefits.

\section{II.4. Greater support for the poorest and richest families...}

This brief historical presentation shows that transfers are multi-oriented. Some recent papers have attempted to evaluate how they benefit families with children compared to childless households. Overall they show that transfers are larger for families with a youngest child aged under 3, and more generous for bigger, better-off families. Across all families, the average amount of child-related transfers is U-shaped (Figure 7; Bechtel, 2005): low-income families receive a higher amount per child than median earners, basically because of the means test for the basic PAJE allowance but also because they receive higher amounts of social and housing assistance. By contrast, the tax-relief mechanism of the "quotient familial" is clearly beneficial to richer households, and explains why the average support per child is much higher for them. In comparison with other OECD countries, the ratio of transfers received by low-income families in France compared with high income ones is relatively low and represents about half the OECD average (Adema and Thévenon, 2008). 
Figure 7: Gain in disposable income due to the presence of children

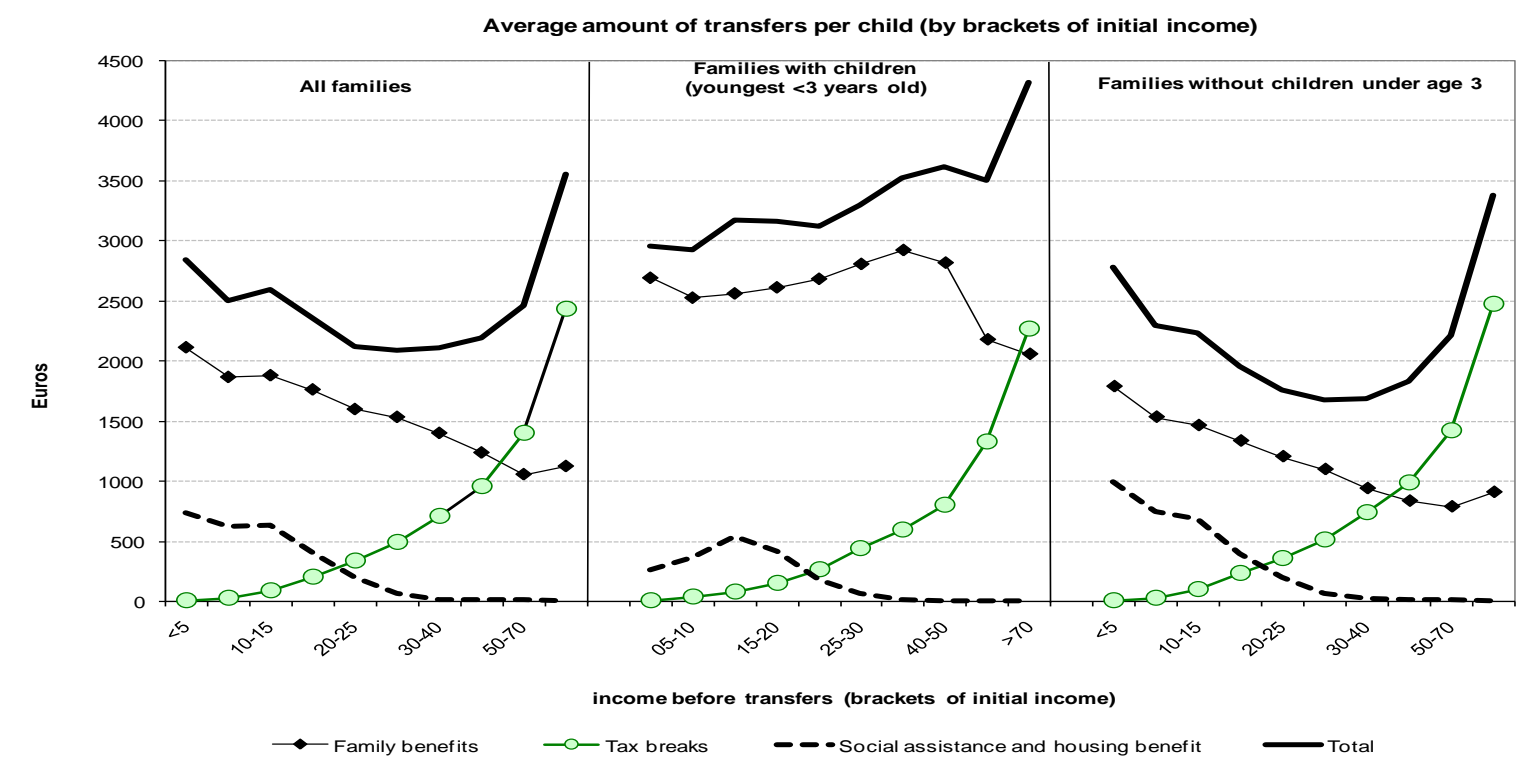

Source: Bechtel et al. (2005); Simulation of the legislation in 2004 with income in 2001.

\section{II.5. ... and to households with children under 3 years old and larger families}

Globally, transfers received by families help reduce the income gap between households with and without children, and thus contribute to reducing income inequalities as well as the poverty rate. This fell to $7.2 \%$ after transfers to families with children were introduced, from $21 \%$ before (Courtioux et al., 2005). In the case of households with a child under age three, child support has increased together with primary income, as a result of the tax reduction for childcare costs. Because support increases with the number of children, transfers are greater for large families in France at all income levels, whereas they are proportional to the number of children in the majority of European countries (Math and Meilland, 2007).

Figure 8 compares the progressive increase in support according to the different childcare solutions, by household income. It clearly illustrates the sharp increase in household income thanks to the childcare allowance when parents employ a registered childminder. For one-child families, the average support is clearly higher than the home-care allowance (CLCA) for most households, whatever their position in the distribution of income. By contrast, the figure changes for families with two (or three) children: households in the first four deciles of income gain far more from the home-care allowance than from the benefits obtained to compensate for childcare costs. 
Figure 8: Childcare support by income level

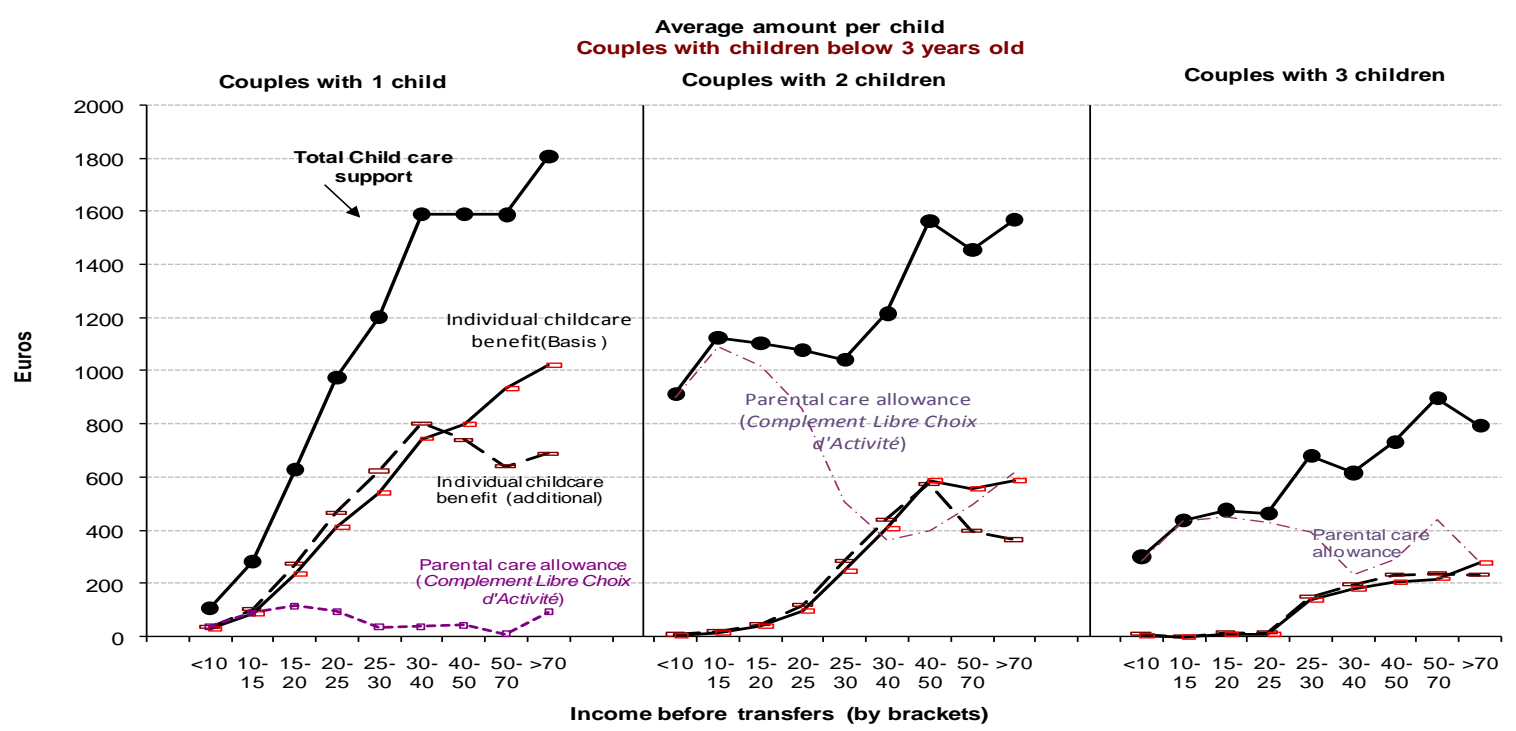

For details about the items, see box 2.

Source: Bechtel et al. (2005); Simulation of the 2004 legislation with income in 2001.

\section{II.6. Comprehensive provision of childcare services to reconcile work and family life.}

Excluding tax allowances for childcare costs, the effective tax rate of a second worker in the household is clearly below the OECD average, but the incentive for a second worker rather than an increase in the first earners' labour supply is especially low, given the "quotient conjugal" mechanism. The net cost paid by two working parents with two children using fulltime care is, in terms of percentage of household net income, about the OECD average (Barber and Immervoll, 2005). Nevertheless, tax breaks contribute to reducing childcare costs and levelling the differences between the cost of a place in a day nursery and the employment of a registered childminder.

This support improves the work-life balance and complements the relatively comprehensive provision of childcare services provided by the system of public day care centres, as well as the early enrolment of children in preschool (écoles maternelles). As already stated, investment in early childhood services is comparatively high in France, and represents almost one tenth of the total amount spent on families (Figure 6). Moreover, day nurseries accept infants into day care immediately after the end of maternity leave, i.e. from the age of two or three months, and are open for most of the day (7-8am to 6-7 pm). That is very different from the situation in the Nordic countries, for instance, where collective public care services only become available once the child is one year old.

Although day care centres are open to infants from very young ages, their effective contribution to childcare of children under preschool age remains quite limited in comparison to the other formal or informal childcare solutions. A 2002 survey on childcare estimated that only $10 \%$ of children under three are enrolled in day care centres, while most of them $(61 \%)$ are looked after mainly by their parents during weekdays, $21 \%$ are cared for by subsidized childminders, $7 \%$ by grand-parents and only $1 \%$ by nannies at home (Blanpain, 2006).

By contrast, nursery schools (écoles maternelles) are certainly a key component of overall child care provision. They were created in 1881, and considerable investments were made after the 1970 s to increase the total number of places. The state is motivated to increase 
preschool capacity since it is relatively cheap compared to the cost of other childcare solutions (Adema and Thévenon, 2008). These nursery schools are free of charge for parents (except for lunch) and often accept children from age two. They provide care support to working parents and are relatively compatible with full-time work since children are in school from $8.30-9$ am to $11 \mathrm{~h} 30-12 \mathrm{pm}$, then from 1.30 to $4.30 \mathrm{pm}$. Most nursery schools also provide lunch and care after school hours (until 6-6.30 pm).

The role of preschools is confirmed by the fact that about $37 \%$ of children are enrolled in preschool at age 2 and $97 \%$ from age 3 . There is universal coverage at age 4 - combined with other childcare solutions since only $14 \%$ of two-year olds attend school on a full-time basis, and $21 \%$ on a part-time basis. Most children can attend after-school care from $4.30 \mathrm{pm}$ to 6-6.30 pm, but about two thirds of 2-6 year-old children are cared for by their parents after school and only $17 \%$ use the after-school care facilities.

The contribution of the school system to childcare extends beyond preschool. School days are relatively long in France compared with other European countries, and out-of-school care is frequently provided (Ananian and Bauer, 2007). In all, 56\% of children in primary and secondary school have lunch at school, and $21 \%$ attend after-school care. The use of out-ofschool care is especially frequent among women who work on Wednesdays (French nursery and primary schools are closed on Wednesdays). However, about one in five women care for their children on Wednesday even when they work all, and almost $27 \%$ of school-age children are cared for by their grand parents or another family member.

To summarize, one of the main characteristics of French family policy is the U-shaped financial support to families. It includes some anti-redistributive effects but has contributed to lowering the poverty rate of families with children to $7.2 \%$, compared with a rate of $21 \%$ before the transfers were introduced. Income support is higher for families with three or more children, whereas support is generally proportional to the number of children in other European countries. Furthermore, comprehensive and diversified support for childcare is also granted to families with children aged under 3 through the provision of childcare and preschool services early in the child life-cycle, but also through subsidies for the various childcare solutions. However, this variety of measures is not sufficient to alleviate the inequalities in childcare support or in the use of paid assistance. Thus, women in the lower range of household income distribution are clearly encouraged to withdraw from the labour market to care for their children, while those with higher earning potential benefit from greater support to employ nannies and stay in employment.

\section{II.3. The impact of policies on fertility and the work-life balance}

Basically, family-friendly policies are expected to impact fertility because they reduce the cost of having children and improve the work-life balance. These policies include a large range of institutional instruments including tax credits, cash benefits, and other financial transfers that aim to limit the potential loss of well-being that the presence of children may produce in a household. Some benefits or transfers provide specific assistance for low-income families or support for housing; others are directed at helping parents to reconcile work and family life, while benefits and tax allowances can be designed to help families meet childcare costs. Childcare services and parental leave provisions are also of prime importance in giving parents the opportunity to combine employment with family and care responsibilities, and therefore impact the opportunity cost of parenthood. Tax transfers or subsidies targeting the 
labour market impact both the direct and the opportunity costs of children. In this case, policies can create reverse incentives on childbearing.

\section{III.1. Some difficulties in measuring policy impact}

In spite of these contrasting expected effects, cross-country analyses suggest that total fertility rates are higher in countries with wider childcare availability, lower direct cost of having children, higher part-time availability of parents and longer parental leave. However, it is difficult to evaluate the precise impact of each of policy variable. For instance, it is difficult to measure and define the scope and boundaries of policies (Gauthier, 2007). One might argue that in some cases the whole institutional setting, rather than specific policies, make the country more child- or fertility-friendly. Thus, the conventional limits of policies must be narrowed in order to make meaningful cross-country comparisons, or broadened in order to capture any systemic coherence between them that is not underpinned by the same goals but may be of importance in reconciling fertility decisions with other aspects of life.

Another challenge is to capture the potentially complementary nature of instruments, i.e. the fact that one instrument has an effective impact only if combined with another, or if the associated support exceeds a given threshold. The effectiveness of policy instruments may depend on the existence of multi-faceted and combined support in cash, services and time provided continuously over the childhood period to address the different aspects of childrearing and the evolution of needs over the family life-cycle. However, few quantified data on how such institutional complementarities affect fertility behaviour are available as yet. Econometric evidence of the impact of specific policy initiatives is much more abundant. Assessing this impact is a challenging task, however:

- First, there are obvious time lags in the adjustment of reproductive behaviour to policy changes, and such lags make it difficult to assign the impact of specific instruments or specific policy changes to the changes that can be observed.

- A related issue is that short-term impacts can be identified quite easily, while long term effects are more difficult to apprehend. For example, it is difficult to know whether policy changes will impact only the timing of birth or also the completed fertility rates. This is important to acknowledge, however, since there seems to be no deterministic relation between the changes in birth timing and the evolution of fertility rates in European countries (Sobotka and Toulemon, 2008).

- Thirdly, both fertility and labour market behaviours are decided simultaneously and this may induce some endogenous explanatory variables, such as mothers' labour supply. This problem is now treated quite effectively when longitudinal data are available.

- A fourth difficulty lies in estimating the exact degree to which policy measures compensate for the cost of children, a factor which varies according to the household's economic and demographic situations. Most cross-country comparisons do not account for such inter-group heterogeneity and focus on average values. However, policy impact may vary across socio-demographic groups, such as ethnic group or socioeconomic status, and also according to the type of relationship between the parents (Sleebos, 2003). There may even be a polarized attitude or reaction to policies. The impact of policies also varies by birth parity, although most papers focus on aggregates figures.

- Another related issue is to define the scope of policy measures since these can impact the behaviour of population subgroups not directly targeted by the measures. As we will see, parental leave payments to two-child families in France may have had a considerable 
impact on the behaviour of both smaller and larger families. Moreover, very active policies, even targeting specific population groups, may act as a signal of support to families and influence a larger proportion of families by contagion. Differences-in-differences estimation is weakened in the presence of such a process.

- This possibility leads to a sixth difficulty: the potential endogeneity of policies. The development of family policies can surely boost fertility, but they may also be developed as a consequence of such a boost. Evidence from long-term series, for example in Sweden, shows that childcare policy has been developed in parallel to the expansion of female labour participation, but was not a pre-requisite to it (OECD, 2005).

- Last but not least, financial incentives are certainly not the only policy channel for impacting fertility decisions, and the other channels should be considered when evaluating fertility responses to policies and institutions. For instance, one effect of institutions is to reduce uncertainty and to enable people to make long-term commitments (such as childbearing). However, several conditions need to be met for them to have such an effect. Long-lasting policies are necessary in order to maintain people's trust and convince them that no profound changes will occur in the future. Continuous and diversified policies are also needed to guarantee long-term support and create 'systemic' coherence. The existence of coherent support, balancing benefits in cash and in kind, and providing continuous support to parents as their children grow up is certainly a precondition for effective policies. This is a key aspect in explaining France's performance, and goes beyond direct financial incentives.

\section{III.2. Some evidence from comparative studies: from the impact of financial incentives to the assessment of work-life balance policies}

Given these obstacles, assessing the exact impact of family policies on fertility is an intricate business. One approach is to make cross-country comparisons that investigate the effect of policies on fertility rates in industrialized countries. Most of these studies consider the aggregated level of TFR, and merge the data for all countries, even if they allow countryspecific effects. They use either time-series cross-section data or longitudinal data.

In a survey published in 2003, Sleebos asserted that findings are often inconclusive or contradictory, partly because of methodological differences. However, a review of these studies suggests a positive but weak relationship between reproductive behaviour and family policy. The same dubitative statement is reiterated by Gauthier (2007). One obvious reason for the lack of evidence is that the influence of policies can only be detected in the long-term. However, both authors point out that the more obvious and robust results concern the impact of cash benefit and transfers, whereas the impact of work-related policies is more contradictory: the duration and payment of maternity leave generally have a rather weak impact, whereas some studies conclude that childcare availability and/or affordability have a greater one. Flexible working hours and the availability of part-time work are important factors influencing fertility. Thus, a key issue for fertility decisions appears to be the possibility of combining a career and a family. For that reason, attention should be paid to policies that aim at reconciling work and family life.

Among the most significant studies assessing the impact of cash transfers, Blanchet and Ekert-Jaffé (1994) investigate the effect of family benefits on the TFR of 11 industrialized countries in the period from 1970 to 1983. They constructed a family policy index that measures the global generosity of financial support through cash benefits, tax relief and parental leave compensation, and found that such a package had a fairly weak impact, and 
that French family policy could lead to an extra 0.17 child per women compared with other developed countries such as the UK. Such an impact is not insignificant, but shows that crossnational differences in fertility level are only very partially explained by differences in cash support to families. Moreover, no major fertility upswing may be expected from such support.

Gauthier and Hatzius (1997) modelled the dynamic relation between fertility rates and policies for 22 OECD countries over the period 1970-1990. They found that neither the duration of benefits nor the amount of benefits appeared to be significantly related to fertility. By contrast, direct cash benefits were found to have a positive and significant effect, albeit a small one. The authors also considered the differences in policy impact according to birth parity and found that benefits had a greater effect for the first child. One of their conclusions was that targeting benefits on the third child, as is the case in France, is unlikely to increase fertility. Overall, the magnitude of the effect is therefore small, since they estimate that a $25 \%$ increase in family allowances would result in an average fertility increase of about 0.07 children per woman. However, they also observed differences in responsiveness across groups of countries. Basically, a greater impact was found in Scandinavian countries and was interpreted as the effect of the co-variation of in-kind support in these countries. Thus the authors (indirectly) stress the importance of institutional complementarities although they could not quantify them directly.

Comparing changes in cross-section data, Castles (2003) argues that the provision of child-care facilities for children aged $0-3$, which is crucial to early re-entry into the labour force, may have been the main factor contributing to the reversal of the relationship between fertility rates and female labour market participation in OECD countries. Micro-evaluation evidence is, however, less conclusive. While a positive impact on fertility of reduced childcare cost and increased childcare availability was estimated by Di Prete et al. (2003) and Del Boca et al. (2007), no statistically significant impact on childcare characteristics was reported for example by Ronsen (2004) for Norway and Finland, Hank and Kreyenfed (2003) for Germany or by Andersson et al. (2004) for Sweden.

More recent studies confirm the impact of standard family policies and provide evidence of their effect on the labour market and work organization. D'Addio and Mira d'Ercole (2005) analysed cross-country differences in total fertility rates in 1999 for 19 OECD countries. Their investigation was based on models that allow for dynamic effects, potential heterogeneity between countries, and endogeneity of some of the explanatory variables. They find evidence that transfers to families with children, as well as the provision of services to working parents to help them cope with care responsibilities, have a positive impact on childbearing. The impact is, however, relatively weak: a one-week increase in the total length of parental leave would on average increase the total fertility rate by $0.3 \%{ }^{4}$ (when the impact is estimated with pool mean group estimators including time effect). A 1-unit increase in the percentage of wages replaced during maternity leave or in the income transfers to families produces an increase in TFR of $0.9 \%$ and $1 \%$ respectively ${ }^{5}$. The study also suggested that an increase in female labour market participation, in the share of women in

\footnotetext{
${ }^{4}$ The interpretation of this result is not straightforward, however, since leave provisions are often longer in countries with fewer out-of-home caring facilities. These facilities are not included in the model because of lack of time series data.

${ }^{5}$ Net transfers to families with children are computed as the difference between the average effective tax rates of singles without children earning the average wage and a married couple with two children aged 6 and 4, where one spouse earns the average wage. The estimated impact means here that an increase in transfers to families by $25 \%$ translated on average into a long-run increase of 0.005 children per women. This increase is half-way between the increases of 0.04 children per women (following a $25 \%$ increase in the family benefit index) in Ekert-Jaffé (1986) and of 0.07 children per women reported in Gauthier and Hatzius (1997).
} 
part-time work, and in the ratio of female to male hourly earnings all have a positive impact on fertility.

Del Boca et al. (2007) also modelled the role of childcare arrangements, parental leave, family allowances and labour market flexibility, but adopted an individual-based approach by and on women's fertility and labour supply decisions. Their results, based on the ECHP, show that a non-negligible portion of the differences in labour force participation and fertility rates of women in six European countries (including France) can be attributed to institutional differences, but the impact varies according to educational levels. Childcare availability and optional leave have larger impacts on fertility and participation decisions at lower educational levels. The parameter significance on fertility is, however, weak. By contrast, labour market policies, such as opportunities for part-time employment have a greater impact on women with higher education. In all cases, the impact is more significant and stronger on labour supply than on fertility.

When assessing the effectiveness of policies in raising fertility levels, an important issue is also to determine whether these policies impact the "completed" fertility rates or only the timing of births. In the first case, policies would have a long-term effect, but in the second only a temporary one. Studies that distinguish between the two using age- and parity-specific fertility rates, tend to conclude that the impact is more significant on the timing of fertility than on the total number of children (Sleebos, 2003). For example, Andersson (2001) suggests that the introduction of a "speed premium" in the Swedish parental leave system has accelerated childbearing decisions by reducing the spacing between first and second births.

\section{III.3. Some evidence for France from the literature on fertility and female labour market behaviour}

Only a limited number of the papers investigating the impact of family-oriented policies on fertility in France can be used to interpret the above-mentioned specificities in fertility trends. Contrary to the comparative studies we have discussed, most of the analyses on France are based on micro-behaviour and individual data. Some of these studies have focused on the impact of income support on fertility. They consider either total income support taken as a whole, or the impact of tax breaks on fertility. Other, more recent studies have considered the effect of specific work-related policy measures on fertility and female labour market participation. In particular, many studies have focused on the effect of the parental leave benefit (the APE) on female labour market behaviour, but only one has focused on childbearing. Many studies also analyse the impact of childcare characteristics (cost and availability) on the female labour supply but, to our knowledge, none have investigated their specific impact on fertility. Nevertheless, these papers shed light on the relatively comprehensive support that has helped many women combine full-time work with the birth of a first child. Policies that reconcile labour market participation and first motherhood do appear to be very important. There are, however, no studies specifically investigating the role of flexible working hours or part-time work on fertility.

\section{III.4. A limited impact of financial incentives, except for higher parity births}

Ekert (1986) was among the first to estimate the impact of financial (non workrelated) transfers to families on fertility. She evaluated the effect of direct cash benefits (including the "universal" allocations familiales, the means-tested complément familial, and housing benefits) on fertility in the late 1970s and observed a significant but limited impact since their contribution to fertility rates represented about 0.2 children per woman. The author 
estimated that full payment of child-related costs would increase fertility by a mere 0.3 children per woman. As stated previously, Blanchet and Ekert (1994) found a similar impact from a cross-country comparison.

Ekert et al. (2002) also suggested that family policy is an important factor that reduces differences in fertility behaviour between socio-occupational categories, especially compared with countries like the UK. Nevertheless, the majority of women become mothers in France, and the propensity to have a second child depends very little on social categories. In the UK, where support for families and working mothers is far less developed, the polarization of fertility behaviour across social groups is far more pronounced, and starts from the first child.

A more recent paper by Landais (2003) scrutinizes the impact of the quotient familial on fertility at parity 3 . To do so, he estimated the impact of a 1981 change in tax legislation that considered a third child as a full adult for tax purposes, instead of half an adult in the tax allowance calculation (see box 1). He also concluded that there was a positive but very weak impact: a $1 \%$ variation in tax allowances for households with two children produced a relative proportionate increase of less than $0.05 \%$ in the probability of transition to a third child. Landais also observed that the sensitivity of fertility behaviour to tax incentives increases with income (and thus the size of the incentive). There is, however, a time lag of between 5 and 10 years before the effects are fully disseminated and can be evaluated.

\section{III.5. The 1994 parental leave reform: a limited (positive) impact on fertility...}

Breton and Prioux (2005) also investigated the role of family policies on the transition from two to three children and looked at trends in a more long-term perspective. They concluded that the measures targeting the third child had a visible impact on birth timing. These measures may also have contributed to the stability or even the slight increase in the probability of having a third child, especially with the Allocation Parentale d'Education introduced in 1985. This probability has decreased as support policy has moved from focusing on the third birth to the second. The authors observed roughly the same cyclical variations in the probability of having a second and third child during the 1970-2000 period, but a greater magnitude of variations when support for 3-child families was increased in the early 1980s. However, they could not quantify this impact without predicting what would have happened without the policy changes. Observing the relatively similar cyclical trends of the probability of having a child at parity 2 and 3, they suggested that policy may have had an impact beyond its target (families with 3 children), i.e. on fertility behaviour at lower parity, by the contagion effect from the secure climate created by the policy and the widespread communication campaigns that accompanied the reforms. 


\section{Figure 9: Policy support for a second and third child and associated fertility trends}

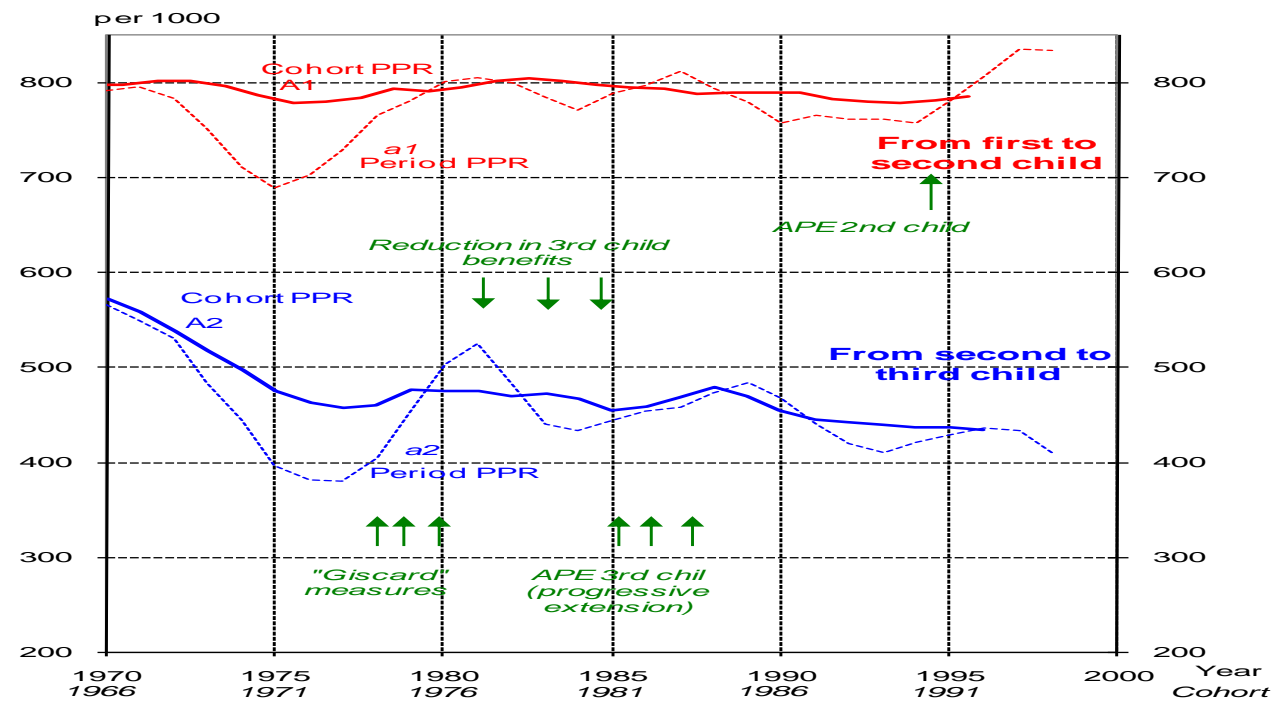

Source: Breton and Prioux (2005)

Laroque and Salanié $(2004 ; 2005 ; 2008)$ investigated the role of financial incentives through tax and benefit transfers received by families. They used a micro-simulation model with endogenous female labour force participation and the fertility response to financial incentives. However, their three papers produced rather different and sometimes contradictory results. Basically, Laroque and Salanié (2005) stressed two main differences between their first and second papers. The first was that the time horizon of benefit receipt was not sufficiently taken into account. Second was that they included fewer variables in the fertility equation in the first generation of models. Thus, the early results were marred by bias from omitted variables and, according to the authors, the 2005 publication provides more reliable estimates. The third paper pays more attention to identification issues and runs different identification assumptions. For that reason, we will only consider the results of the later publications that provide ex ante micro-simulations of the impact of financial transfers received by families. Here again, the impact of financial support is significant but relatively weak. In all, the costing elasticity of the "demand" for children is estimated at 0.2 in the 2005 paper; a $25 \%$ reduction in the cost of children would increase fertility by only $5 \%$. However, the responsiveness of fertility behaviour varies with birth parity: the higher the birth order, the more sensitive the fertility behaviour to financial variations. Thus, for example, the extension of the APE that encourages mothers of a second child to leave the labour market increases the number of births by an estimated 3.7\%, representing an increase of $10.9 \%$ in births at parity 2 , minus a $2.4 \%$ drop in the number of births at parity 3 because the birth of a third child then became less attractive ${ }^{6}$. In all, these estimates should be interpreted very cautiously since they vary with the strategy used to identify labour and fertility decisions. Moreover, they all are based on a very limited (and selected?) sample of births ${ }^{7}$ and quite heroic assumptions are needed to extrapolate these results to the overall population.

\footnotetext{
${ }^{6}$ Note, however, that this result is very sensitive to the estimation strategy. The above-mentioned result is indeed in contradiction to their previous paper, where they estimated that financial incentives would have a considerable influence on fertility at parity one, but none for two-child or larger families (Laroque and Salanié, 2004). In their most recent paper, the authors found, conversely, that the first and third births are more sensitive to child credit than the second (Laroque and Salanié, 2008).

${ }^{7}$ The simulations are based on just over 2,600 women with a newborn babies, i.e. far fewer than the annual variation in the number of births that stood at about 10,000 in the 1990s. There is thus no guarantee that the model would accurately account for variations in total births that are much larger than the periodic variations.
} 
However robust their estimation, one should be cautious in using these results to assess the effectiveness of financial incentives on fertility behaviour. Some restrictions on the sample design ${ }^{8}$ and on the fertility equation can be questioned. Moreover, ex ante simulations are certainly insufficient to assess the impact of policies, and must be complemented by ex post studies based on actual behaviours.

In this perspective, Piketty (2005) also aimed to quantify the effect of parental leave compensation (APE) on both fertility and women's' labour supply in an ex post evaluation using both labour force surveys and the 1999 Family Survey. The extension of the allowance for the birth of a second child in 1994 served as a natural experiment. Here, the challenge was to control for possible windfall effects, i.e. for the fact that some women would have had a child or left the labour market without the change in legislation. The effects on fertility are hard to quantify, but Piketty argues that the extension of the APE would not have explained more than 20-30\% of the increase in the total births observed from 1994 to 2001 (at most $10 \%$ of third births and between $10 \%$ and $20 \%$ of second births).

\section{III.6. ...but a larger (negative) impact on female labour market participation}

According to Piketty's results, the effects on female labour force participation are more spectacular, with payment of the APE to mothers with two children (with the youngest under 3 years of age) inducing between 100,000 and 150,000 withdrawals from the labour market. Thus, between $50 \%$ and $70 \%$ of the 220,000 full-rate APE recipients would not have left the labour force at the second birth if they had not received the benefit.

The author also pointed out the cumulative effect, since receiving the APE for a second birth appears to have induced some 50,000 mothers with 3 children to leave the labour market after the third birth. Thus, the APE reform resulted in an estimated total of 150,000 and 200,000 interruptions of female labour market participation. Moschion (2007) argues that women anticipated their labour market withdrawal: before 1994, mothers left their jobs after a third child; after 1994 they were more likely to do so after second. She concludes that this effect may prove the role of financial incentives.

Finally, Piketty's results also showed that mothers with two children do not seem to have suffered particular difficulties in returning to the labour market since their probability of working increased over the period. A similar conclusion was reached by Thévenon (2007) who observed that the probability of being in employment (full-time) increased in about the same proportion as for childless women or mothers with one child in the period 1996-2005, after a lag that may be explained by the extension of the APE.

\section{III.7. A large number of women in full-time employment before the birth of a second child}

This trend illustrates the specific situation in France of female employment and the work-family balance. Compared to other OECD and European countries, the employment rate of women aged between 15 to 64 years is just above the OECD average at 58.6\%. If we look at the correlation between the fertility period and female employment rates in 2005 , we can see that compared to other countries with same rate of female employment, the fertility rate in France is relatively high (especially compared to continental, southern or eastern European countries, Korea and Japan). Of course, the correlation can be viewed the other way round

\footnotetext{
${ }^{8}$ For instance, the sample did not include households with a retiree, a self-employed person or a civil servant; it also focused on women who had completed their schooling more than two years previously to avoid dealing with the schooling $v s$. work decision.
} 
with the less positive interpretation that, for a given fertility rate, the female employment rate is lower in France than in Nordic European and Anglo-Saxon countries (US, Australia, NewZealand and the UK). However, one difference with respect to this last group of countries is that full-time employment remains the norm in France, although part-time work rose significantly during the 1990s (Thévenon, 2007). In France, as in Denmark, Canada, Finland, Portugal or Sweden, the most frequent situation is clearly both parents in full-time employment (Aliaga, 2005). Another specific feature of France compared to other continental European countries is the way in which the labour market behaviour of French women adjusts to each stage in the family formation process. The effect of the first birth on withdrawal from the labour market is very weak, and weaker than for higher parity births (Thévenon, 1999; 2006). Furthermore, the full-time employment rate is more sensitive to the number of children, and especially to the presence of a third child, than to the age of those children. Parttime work concerns mothers with two or three children, and implies relatively long working hours compared with other European countries (Thévenon, 2007; Chaupain-Guillot et al., 2007).

\section{III.8. Childcare costs have more impact on the use of paid care than on the female labour supply}

In this context, it is important to consider policies that primarily affect the female labour supply where it is not possible to consider simultaneously their potential induced impact on fertility. Most studies limit their investigation to the effect of institutional variations on the use of policy measures and female labour supply. Only a limited number of such studies exists in France and these mostly examine the impact of childcare costs on the demand for formal paid childcare and female labour supply. Chone et al. (2004) found that, overall, childcare costs impacted the use of paid care but had only a very weak effect on female labour market participation. These costs, together with female potential wages, have a stronger and more significant effect on working hours. These estimates show that withdrawal of the APE at parity 2 would have a significant impact on female labour force participation $(+11 \%$ of mothers of 2 children with the youngest aged under 3 ) and on the use of formal paid childcare $(+4 \%)$. However, the global impact on the employment rate would be moderate, with an increase of about $4 \%$, due the relatively small share of population concerned by the APE. By contrast, tax reductions related to childcare costs would have only a limited impact.

\section{III.9. A probable (but uncertain) effect of early preschool enrolment of children on full-time female labour supply}

Comparative analysis suggests that preschool entry of 3 year-old children is a turning point since there is subsequently a significant increase in the full-time female employment rate - a higher increase than that observed among mothers of older children (Thévenon, 2007). The exact contribution of early preschool enrolment on the female labour supply is uncertain, however. De Curraize (2005) analyses the effect of early school enrolment (at age 2 ) on the duration of the mother's interruption of labour market participation and finds it impossible to conclude to a positive effect. Moschion (2007) finds that providing mothers of two-year old children with childcare facilities modifies the effect of fertility on the mothers' labour supply and may have a positive impact on combining work and family life. In particular, Moschion finds that having more than two children has a negative effect on labour force participation and hours worked in French départements with relatively low 2-year old enrolment rates. Conversely, the effects are positive in départements where preschool enrolment is high. However, the estimates are not significant because of the lack of precision, 
and should therefore be interpreted cautiously. Clearer evidence is found on the impact of early preschool enrolment on labour supply of lone mothers, while no negative effects on child development are simultaneously observed (Goux and Maurin, 2008).

\section{Conclusion: towards a broader policy approach to fertility regulation?}

As stated in the first part of this paper, France has relatively high total fertility rate compared to other European countries, and these rates have increased significantly since the mid-1990s. The rate remains quite stable after controlling for tempo effects, however, suggesting that the increase in TFR may reflect some sort of catch-up effect among women who had postponed childbearing. In a longer-term perspective, the decrease in completed fertility reflects the generalization of the two-child norm. The proportion of women remaining childless in France is also lower than in many other European countries.

Family policies do help women to combine motherhood with work. First, financial transfers through cash benefits and tax allowances reduce the "cost" of children but their direct effect on fertility appears to be limited. The measured effects of transfers are estimated to account for at maximum one tenth of fertility rates. Although far from negligible, these effects are not very large. They nonetheless significantly contribute to maintaining fertility rates close to replacement level. Second, substantial support is also provided to families with children under the age of 3 or 6 years to alleviate the cost of childcare, and the literature suggests a large response to this financial support in terms of female labour market participation and coordination of family formation. However, to account for the stylized facts' reviewed in the this paper, the financial aspect is certainly only one part of the story. For instance, one reason why childlessness is less frequent in France is certainly that the birth of a first child is more compatible with employment, even full-time employment, and does not hinder future career development. One argument for this is that employment stability increasingly appears to be a precondition for entry into parenthood (Toulemon and Leridon, 1999; Méron and Widmer, 2002). Thus, empirical evidence shows that women who experience a period of unemployment postpone the birth of the first child, compared to both inactive and employed women, and this is more prevalent for less qualified women and younger cohorts (Méron and Widmer, 2002). Among the individuals who intend to have a child, the experience of unemployment also reduces the probability of realizing their intention within a five year period (Toulemon and Testa, 2005).

The more frequent (or more rapid) entry to first motherhood in France may be explained by the fairly comprehensive support received by women who combine motherhood with full-time labour market participation. As stated in the second part of this paper, this support is relatively diversified in terms of financial benefits, childcare subsidies and provision of services, and is also continuous over the childhood period (Adema and Thévenon, 2008). Such comprehensive support is likely to address family needs and secure the transition to motherhood and employment. This broad set of measures creates a systemic coherence that lowers the potentially irreversible consequences of fertility on lifelong career development patterns. It may also be a crucial ingredient of the "trust" needed for policies to be effective. It is also one reason why women do not forgo having a second or a third child, and explains why the decision to have children or to be in employment is less polarized by socioeconomic status in France than elsewhere.

However, it is tricky to identify and quantify the extent to which policies contribute to establishing such a secure climate. In order to really understand the processes involved, it may 
be necessary to investigate further to find out if and how labour market flexibility (i.e. flexitime or part-time working, as well as increased mobility between jobs observed during lifetime careers) influences fertility decisions. Contrasting consequences can indeed be expected: on the one hand, flexible workplace practices can have a positive influence on fertility decisions by helping parents to find a satisfactory balance between work and family life; on the other hand, the additional job instability or the unwanted consequences on career development can add to the uncertainty that leads couples either to postpone births or to forgo having children. Only a few studies have started to investigate these consequences on fertility intentions in France. Cette et al. (2005) suggest that the organization of working life influences the intended number of children, and more significantly for individuals with a higher socioeconomic status. The lack of time and of predictable working hours may influence the timing of childbearing. Pailhé (2009) found that flexible work schedules or the provision of childcare by employers may positively impact intentions of having a first child. All these working conditions are important to capture, since differences in workplace practices in European companies seem to add to the role of public support rather than compensate some lack of public support (Thévenon, 2008).

We may also need to better understand the role of institutions as a "filter" capable of modifying the way in which an uncertain environment over the life-course affects different population groups (Blossfeld et al., 2004). This is an important issue since we observe that highly educated individuals achieve their fertility intentions more frequently, whether or not they intend to have a child (Toulemon and Testa, 2005). More fundamentally, one challenge is to better understand how micro-level determinants of the life-course, and macro-conditions and institutions interact to shape the transition to parenthood (Billari, 2004). This means that we need to identify how institutions temper the effect of macro-level situations on micro-level factors. We also need to identify the extent to which the effective impact of family policy is conditional upon the complementarity of family support over the life-course, and thus how such complementarities shapes the transition to motherhood.

However, even such a sophisticated framework would give a misleading picture of the fertility situation in France if it did not take into account the relatively positive attitude towards family in that country, as observed by Testa and Grilli (2006) in their European comparison of fertility preferences. As highlighted by Toulemon et al. (2008), 95\% of French people want at least one child, a proportion very similar to the high levels observed in most other European countries. There are regional disparities, however, since the "preference" for children is more widespread in southern regions. This is interpreted by Toulemon and al. (2008) as an indication that French fertility ideals are linked to its cultural past (southern regions being more representative of that past). By contrast, the ideal number of children among people with a confirmed desire to have a child is extremely high in France, with the highest score at 2.34 (just behind Ireland), and less heterogeneous between regions. As argued by the authors, this positive attitude towards large families may be partly nurtured by the multi-faceted French family policy. 


\section{References}

Adema W., Thévenon O. 2008. Les politiques de conciliation du travail et de la vie familiale en France au regard des pays de l'OCDE. Recherches et Prévisions 93 :51-72.

Aliaga C. 2005. Conciliation entre vie professionnelle et vie familiale : des écarts entre les femmes et les hommes. Statistiques en bref 4/2005 : Eurostat.

Ananian S., Bauer D. 2007. Le temps périscolaire. Etudes et Résultats : 611, DREES.

Andersson G. 2001. The impact of labour-force participation on childbearing behaviour: procyclical fertility in Sweden during the 1980s and the 1990s. European Journal of Population 16: $293-313$.

Barber D., Immervoll H. 2005. Can Parents afford to work ? Childcare costs, tax-benefit policies and work incentives. Social, Employment and Migration Working Papers, OECD, Paris.

Bechtel J., Caussat L., Courtioux P., Laib N., Le Minez S. and B. Mirouse (2005), «La politique familiale française : coûts et bénéficiaires ». in Godet M., Sullerot E., La Famille, une affaire publique, CAE : 57 : La documentation française, pp. 409-437.

Billari F. 2004. Becoming an Adult in Europe : a Macro(/Micro)-demographic perspective. Demographic Research (Special coll. 3), Max Planck Gesellschaft.

Blanchet D., Ekert-Jaffé O. 1994. The Demographic Impact of Family Benefits : Evidence from a Micro-Model and from Macro-Data. in Ermisch J., Ogawa N. (eds), The Family, the Market and the State in Ageing Societies. Clarendon Press: Oxford, pp. 79-104.

Blanpain N. 2006. Scolarisation et modes de garde des enfants âgés de 2 à 6 ans, Etudes et Résultats : 497. DREES.

Blossfeld H.P, Klijzing E., Mills M., Kurz K. 2004. Globalization, Uncertainty and Youth in Society: Routledge: London.

Bongaarts J., Feeney G. 2006. The quantum and tempo of life-cycle events. Vienna Yearbook of Population Research : 115-151.

Breton D., Prioux F. 2005. Two or Three Children? Influence of family policy and socioeconomic factors. Population (English edition) 60(4): 415-445.

Castles F. 2003. The world turned upside down: below replacement fertility, changing preferences and family-friendly public policy in 21 OECD countries. Journal of European Social Policy: 13: 209-227.

Cette G., Dromel N., Méda D. 2005. Conciliation entre vies professionnelle et familiale et renoncements à l'enfant. Revue de l'OFCE 92 : 263-312.

Chaupain-Guillot S., Guillot O., Jankeliowitch-Laval E. 2007. Choix d'activité des mères et garde des jeunes enfants: une comparaison européenne, Recherches et Prévisions 90 : 41-54.

Commaille J., Strobel P., Villac M. 2002. La Politique de la Famille, Repères, La Découverte.

Courtioux P., Laïb N., Le Minez S. et B. Mirouse. 2005. L'incidence du système de prélèvements et de transferts sociaux sur le niveau de vie des familles en 2004 : une approche par microsimulation, Études et Résultats 408.

Curraize Y. 2005. L'extension de la scolarisation en maternelle : une expérience naturelle pour comprendre l'offre de travail des mères de jeunes enfants, mimeo. 
D’Addio-Dervaux A., Mira d'Ercole M. 2005. Fertility trends and the impact of policies. Social, Employment and Migration Working Papers, OECD, Paris.

Di Prete T., Engelhardt H., Morgan P., and H. Pacalova. 2002. Do cross-national differences in the costs of children influence fertility behavior? Discussion Paper 355, DIW, Berlin.

Daguet F. 2002. La fécondité en France au cours du XXème siècle. INSEE Première 873.

Damon J. 2006. Les Politiques Familiales, Que-sais-je? 3776. Presses Universitaires de France.

Del Boca D., Pasqua S., and Ch. Pronzato. 2007. Market work and motherhood decisions in contexts, IZA DP 3303.

Ekert O. 1986. Effets et limites des aides financière aux familles: une expérience et un modèle. Population 41/2 : 327-348.

Ekert-Jaffé O., Joshi H., Lynch K., Mougin R., Rendall M., and D. Shapiro. 2002, Fertility, timing of births and socioeconomic status in France and Britain: social policies and occupational polarisation, Population (English edition) 57(3): 475-507.

Fagnani, J. 2007. Fertility rates and mothers' employment behaviour in comparative perspective: similarities and differences in six European countries" in R. Crompton, S. Lewis, C. Lyonette (eds.), Women, men, work and family in Europe, Londres, Palgrave Macmillan, pp. 87-113.

Fagnani J. 2006. Family Policy in France. International Encyclopedia of Social Policy 3: 501506, Routledge.

Fagnani, J. 2008. Childcare Policies in France since the Seventies, Continuities and Changes, Tensions and Ambiguities. in K. Hagemann, K. Jarausch, C. Allemann-Ghionda (Eds.) (forthcoming), Time Policies: Child Care and Primary Education in Post-War Europe, Berghahn Books, New York and Oxford.

Gauthier A. 2007. The impact of family policies on fertility in industrialised countries: a review of the literature. Population Research Policy Review 26(3): 323-346.

Gauthier A., Hatzius J. 1997. Family benefits and fertility: an econometric analysis. Population Studies 51: 295-306.

Goux D., Maurin E. 2008. Preschool enrolment, Mothers participation in the labour market and children's subsequent outcomes. Paris School of Economics working paper.

Hank K, Kreyenfeld M. 2002., A multilevel analysis of childcare and the transition to motherhood in West Germany, Discussion Paper 290, DIW, Berlin.

Hantrais L., Letablier M.Th. 1996. Families and Family Policies in Europe, Longman, Londres/New York.

Héran F. 2002. Situation démographique de la France dans le contexte européen, in Aglietta M., Blanchet D. and F. Héran (eds.), Démographie et Economie, Conseil d'Analyse Economique.

Kohler H.P., Billari F., and J. Ortega .2006. Low Fertility in Europe: Causes, Implications and Policy Options. In F. R. Harris (Ed.), The Baby Bust: Who will do the Work? Who Will Pay the Taxes? Lanham, MD: Rowman \& Littlefield Publishers, pp. 48-109.

Landais C. 2003. Le quotient familial a-t-il stimulé la natalité française, Economie Publique $13: 3-31$. 
Laroque G., Salanié B. 2004. Fertility and Financial Incentives in France. CESifo Economic Studies 50(3): 423-450.

Laroque G., Salanié B. 2005. Does fertility respond to financial incentives?. Document de travail, CREST.

Laroque G., Salanié B. 2005. Does fertility respond to financial incentives? IZA DP 3575D.

Letablier M.Th., Pennec S., Büttner O. 2003. Opinions, attitudes et aspirations des familles vis-à-vis de la politique familiale en France, Rapport de recherche du Centre d'Etudes de l'Emploi 9.

Lutz W. 2007. Adaptation versus mitigation policies on demographic change in Europe. Vienna Yearbook of Population Research: 19-27.

Lutz W., Skirbeckk V. and M.R Testa. 2006. The low-fertility trap hypothesis: forces that may lead to further postponement and fewer births in Europe. Vienna Yearbook of Population Research: 167-192.

Martin C., Math A. and E. Renaudat. 1998. Caring for the very young children and dependent elderly people in France: towards a commodification of social care? in Lewis J. (ed.), Gender, Social care and Welfare State Restructuring in Europe, Ashgate, Aldershot, pp. 139-174.

Math A., Meilland Ch. 2007. Comparaison du soutien financier apporté aux familles dans douze pays européens. Recherches et Prévisions 90 : 55-68.

Méron M., Widmer I. 2002. Les femmes au chômage retardent l'arrivée du premier enfant. Population 57(2) : 327-358.

Meulders D., O'Dorchai S. 2007, The position of mothers in a comparative Welfare State perspective, in Del Boca D., Wetzels C. (eds), Social Policies, Labour Markets and Motherhood, Cambridge University Press, pp. 3-27.

Morgan Ph., Taylor M. 2006. Low fertility at turn of the twenty-first century, Annual Review of Sociology 32: 375-399.

Moschion J. 2007. Reconciling Work and Family Life: The Effect of French Family Policies. Document de Travail du CES, 2007.73, Université Paris 1.

OECD. 2005., Babies and Bosses: reconciling work and family-life. Canada, Finland, Sweden and United-Kingdom, Paris.

Pailhé A. 2009. Work-family balance and childbearing intentions in France, Germany and the Russian Federation. Chapter 3 in UNECE (eds) How generations and gender shape demographic change. Towards Policies Based on Better Knowledge, United Nations, Geneva, pp. 58-82.

Pla A. 2007. Bilan démographique 2007. Des naissances toujours très nombreuses. INSEE Première 1170.

Prioux F. 1994. Du premier au deuxième enfant: maîtrise de la contraception, normes sociales et choix de l'intervalle, in AIDELF (ed.) Les modes de régulation de la reproduction humaine. Incidences sur la fécondité et la santé, PUF, pp. 85-96.

Prioux F. 2007. L'évolution démographique récente en France : la fécondité à son plus haut niveau depuis plus de trente ans, Population 62(3) : 489-532.

Piketty Th. 2005. L'impact de l'allocation parentale d'éducation sur l'activité féminine et la fécondité en France, 1982-2002, in Lefèvre C. (Ed.): Histoires de familles, histoires familiales, Les Cahiers de l'INED 156, pp. 79-109. 
Rallu J.L., Toulemon L. 1994. Period fertility measures. The construction of different indices and their application to France. Population (English selection) 6: 59-130.

Régnier-Loilier A., Léridon H. 2007. Four decades of legalized contraception in France: an unfinished revolution?, Population and Societies 439.

Revillard A. 2006, Work/Family Policy in France: From State Familialism to State Feminism?, International Journal of Law, Policy and the Family, 20(2): 133-150.

Robert-Bobée I., Mazuy M. 2005. Calendriers de constitution des familles et âge de fin d'études, in Lefèvre C., Filhon A. (eds.), Histoires de familles, histoires familiales. Les résultats de l'Enquête Famille de 1999, Cahiers de l'INED, pp. 175-200.

Ronsen M. 2004, Fertility and family policy in Norway - A reflection on trends and possible connections, Demographic Research 10(10): 265-286.

Sobotka T., Toulemon L. 2008. Changing family and partnership behaviour. Common trends and persistent diversity across Europe. Demographic Research 19 (6): 85-138 (Special Collection 7: Childbearing Trends and Policies in Europe).

Sobotka T., Winkler-Dworak M., Testa M.R., Lutz W., Philipov D., Engelhart H., and R. Gisser. 2005. Monthly estimates of the quantum of fertility: towards a fertility monitoring system in Austria, Vienna Yearbook of Population Research:109-141.

Strobel P. 2004. L'État et les transformations de la famille, Cahiers Français Famille(s) et politiques familiales : 57-64.

Testa M.R. 2006. Childbearing preference and family issues in Europe, Report for the Eurobarometer.

Testa M.R., Grilli L. 2006. The influence of childbearing regional contexts on ideal family size in Europe, Population (English edition) 61(1-2): 99-127.

Thélot C., Villac M. 1998, Politique familiale. Bilan et Perspectives, La Documentation Française.

Thévenon O. 1999. La durée du travail féminin en Europe : entre flexibilité et conformité. Une comparaison des relations emploi/famille en Allemagne de l'Ouest, Espagne, France, aux Pays-Bas et Royaume-Uni, Recherches et Prévisions 56 : 47-66.

Thévenon O. 2006. Régimes d'Etat Social et convention familiale: une analyse des régulations emploi-famille. Economies et Sociétés, série Socio-Economie du Travail 27(6) :1137-1171.

Thévenon O. 2007. Labour force participation of women with children: disparities and developments in Europe since the 1990s, EconomiX Working Papers 2008-1, University of Paris West - Nanterre.

Thévenon O. 2008. Are family-friendly workplace practices a substitute for public policy to enhance fertility in Europe?, International Union for the Scientific Study of Population Conference, Barcelona, 11-13 july.

Toulemon L. (2003), La fécondité en France depuis 25 ans, Rapport pour le Haut Conseil de la Population et de la Famille, 77p., http://www.ladocumentationfrancaise.fr/rapportspublics/034000116/index.shtml.

Toulemon L., Léridon H. 1999. La famille idéale : combien d'enfants, à quel âge ? INSEE Première 652. 
Toulemon L., Mazuy M. 2001. Les naissances sont retardées mais la fécondité est stable. Population 56(4) : 611-644.

Toulemon L., Pailhé A., and C. Rossier. 2008, France: high and stable fertility, in Frejka T., Sobotka T., Hoem J., Toulemon L. (eds.) Childbearing trends and policies in Europe, Demographic Research 18: 503-556.

Toulemon L., Testa M.R. 2005, Fertility intentions and actual fertility: a complex relationship. Population and Societies 415. 